\title{
LATHE BREAKDOWN TESTS OF SOME HIGH-SPEED TOOL STEELS.
}

\author{
By H. J. French and Jerome Strauss.
}

\section{ABSTRACT.}

Modern high-speed tool steels are classified according to chemical composition, and the present general tendencies as regards proportions of those elements present which may be classed as impurities are discussed. These data are based on analysis of about 65 lots, representing approximately 40 brands, produced by various manufacturers during the period I919-1922.

Comparative lathe cutting tests are reported for about 25 brands, representing various type compositions. The test used is known as the breakdown test, in which the endurance of tools is measured under fixed working conditions, and a discussion of the behavior of the different groups is given under both moderate and severe service. Measurements of power consumed by various steels in severe tests are likewise reported. A discussion is given of some of the limitations of the competitive breakdown test, and recommendations are made regarding its application.

\section{CONTENTS.}

Page.

I. Introduction. $\ldots \ldots \ldots \ldots \ldots \ldots \ldots \ldots \ldots \ldots \ldots \ldots \ldots \ldots \ldots \ldots \ldots \ldots \ldots \ldots \ldots \ldots \ldots \ldots$

II. Previous investigations. . . . . . . .

III. Classification of modern high-speed tool steels . . . . . . . . . . . . 86

I. Compositions of various types..................... I86

IV. Severe breakdown tests of $\mathrm{I}$ by $\mathrm{I} / 2$ inch roughing type of lathe tool...... I 89

I. Description of tests . . . . . . . . . . . . . . . . .

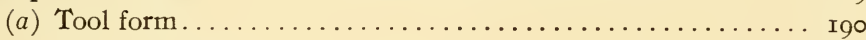

(b) Heat treatment. . . . . . . . . . . .

(c) Test procedure............................... Ig

2. Discussion of results.......................... I94

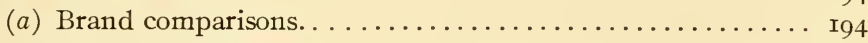

(b) Group comparisons...................... I94

(c) Character of chips produced and failure of the tools...... I95

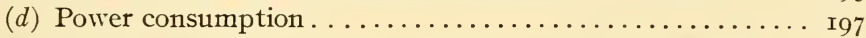

$\mathrm{V}$. Moderate breakdown tests of $\mathrm{I}$ by $\mathrm{I} / 2$ inch roughing type of lathe tool.... I 99

VI. Lathe tests of small tools . . . . . . . . . . . . . . . .

VII. Miscellaneous tests. . . . . . . . . . . . . . . .

I. Secondary hardness and heat treatment. .............. 2 OI

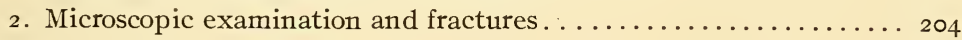

VIII. General discussion. . . . . . . . . . . . . . . . . . . . . . 205

I. Composition $v$. quality of steel and heat treatment........... 205

2. Breakdown tests for the purchase of high-speed tool steels...... 209

IX. Summary and conclusions. . . . . . . . . . . . . .

$\mathrm{X}$. Tables of results . . . . . .

\section{INTRODUCTION.}

Unlike structural steels, which are generally sold within definite limits of chemical composition, most carbon and practically all alloy tool steels are supplied as brands or under trade names. 
There are some advantages to this system, both from the standpoint of manufacturer and purchaser, but it has seriously retarded general dissemination of knowledge concerning different types and in many instances has been responsible for erroneous impressions regarding their properties and applications. This applies generally to tool steels, but in particular to that important class termed "rapid" or "high-speed" steels, with which the authors are exclusively concerned in this report.

It has long been recognized that high-grade raw materials, good melting practice, and great care in fabrication, all based on an intimate knowledge of the product, are necessary in the manufacture of high-speed tool steels, and that variations in the many operations involved, which are closely related to tool performance, may readily overshadow the effects of small differences in chemical composition. However, this condition has frequently been misrepresented, with the result that the importance of chemical requirements has been largely disregarded by purchasers.

In quite a few instances large consumers have selected brands on the basis of performance in so-called breakdown tests in which the endurance of tools is measured under fixed working conditions, though the selling price and power consumption of the various steeis may be introduced in any comparisons which are made. In recent years tests of this type have also been used in comparing the performance of special steels or in determining the effects of variations in heat treatment, despite the fact that Taylor ${ }^{1}$ specifically recommended determining the cutting speed which would produce failure in 20 minutes under otherwise fixed working conditions and described at great length the reasons for following such a procedure.

Comparison of the breakdown and Taylor tests is not within the scope of this report. The former is accepted because it has found commercial application, and a portion of the work described in subsequent paragraphs may be characterized as a critical survey of this method of test. The cutting speeds, feed, depth of cut, and general test conditions approximated those used in a number of cases for the purchase of large quantities of steel.

In studying the results first obtained marked superiority in performance of certain types of steel was observed, so that these alloys are first grouped according to chemical composition, and the resulting classification is used in discussion of results of the

\footnotetext{
1 F. W. Taylor, "On the art of cutting metals," Trans. Am. Soc. Mech. Eng.; 1906.
} 
lathe cutting tests. It is based upon analysis of about 65 lots, representing nearly 40 brands produced throughout the period I919-1922. ${ }^{2}$

Five sets of breakdown tests are described. The first three, which were carried out at high speed with heavy cut and feed, cover comparisons of about 25 brands and are presented to show some of the limitations in test methods which have been used in the purchase of high-speed tool steels. Test series No. 4 was carried out with reduced feed in order to ascertain whether the superior endurance observed for certain groups in the first three sets of tests was maintained under more moderate working conditions in which lower frictional temperatures were produced.

The expense of large tool tests, time, labor, and special equipment required made it desirable to carry out test No. 5 to determine whether comparable results could be obtained with small tools. Results of fracture tests, microscopic examination, and secondary hardness determinations are also included to throw light upon the quality of metal tested or the characteristics of the various steels under heat treatment.

\section{PREVIOUS INVESTIGATIONS.}

No attempt will be made to review the very large number of publications which have appeared since the discovery of the unique and remarkable properties of high-speed tool steels and the presentation of a report by Taylor and White, ${ }^{3}$ which has since been characterized as the most important single metallurgical contribution made in the United States. Much of this more recent information does not have a very direct bearing upon the phases which will be considered, while results of cutting tests of different brands or steels which have appeared from time to time either do not represent the best of the current types or are not strictly comparable on account of differences in material cut, angles, shape and size of tools, etc. Such data as may be introduced to advantage will be referred to in connection with the several features emphasized in subsequent paragraphs, but no selected list of references is appended, as a fairly complete bibliography on high-speed tool steels has been prepared by one of the engineering libraries for the National Research Council and is now in preparation for publication.

\footnotetext{
2 Approximately one-third of all analyses was made by H. Bright, Bureau of Standards, one-third by chemists associated with one of the authors, and the remainder collected from various other sources.

${ }^{3}$ See footnote I.
} 


\section{CLASSIFICATION OF MODERN HIGH-SPEED TOOL STEELS.}

While the essential alloying elements in high-speed tool steels are chromium and tungsten, practically all brands now produced in this country for roughing tools contain between 0.5 and 2.25 per cent vanadium. The term "modern" high-speed tool steels, therefore, refers to chromium-tungsten-vanadium steels (which may or may not contain additional special elements), and little or no attention will be paid to the very few brands still manufactured without the intentional addition of vanadium, particularly as they are inferior in performance to the former types.

The modern steels may be grouped under five headings, as follows: (I) Low tungsten steels; (2) medium tungsten steels; (3) high tungsten-low vanadium steels; (4) cobalt steels; (5) steels containing one or more special elements, such as molybdenum or uranium, and called "special steels."

Their relative importance from the standpoint of number of brands within each group and limits of chemical composition are indicated in Tables $\mathrm{I}, 2$, and 3 , which are based on results of analysis of one or more lots of 39 brands.

About half of these are of the third type or so-called high tungsten-low vanadium steels. The low tungsten type, cobalt steels, and those containing special elements such as molybdenum or uranium are about equally represented, but together do not exceed the number of high tungsten steels. A medium tungstenlow vanadium steel is regularly manufactured in England, ${ }^{4}$ but evidently a similar product is of minor importance in the United States, as only two examples were found in the samples analyzed, and one of these contained high vanadium, which is characteristic of a low tungsten steel. In addition, different lots of both brands were found within the limits of classes I or 3 (Table I), so that the medium tungsten steels may be considered largely as "offheats" and the least important of the first three groups comprising "basic types."

\section{COMPOSITIONS OF VARIOUS TYPES.}

There is no marked difference in the proportions of carbon, manganese, silicon, or chromium found in the different groups. In fact, the average values for carbon and chromium shown in Table I are very nearly the same and much closer than might ordinarily

${ }^{4}$ T. H. Nelson, "Comparison of American and English methods of producing high-grade crucible steels," Raw Material, 4, No I2, p. 424. 
be expected from any such survey as the one under consideration. The principal differences are, therefore, in the proportions of tungsten and vanadium present and whether cobalt or some such special elements as molybdenum or uranium have been introduced.

The three basic types-referred to previously as the low tungsten, medium tungsten, and high tungsten varieties-are often called, respectively, I3, I5, and I 8 per cent tungsten steels, and examination of Table I will show that these values are practically identical with the averages obtained in the present survey. The best known brands of the first type contain about I.75 to 2.25 per cent of vanadium, but there appears to be a second group in which lower proportions of this element, between about 0.75 and 1.25 per cent, are found. The so-called i 8 per cent tungsten steels usually contain about 0.50 to $\mathrm{I} .25$ per cent of vanadium.

The alloys of Group 4, which are regularly produced by a number of manufacturers and therefore not included in the special steels of group 5, may be subdivicied into the following: (a) Low tungstenlow cobalt steels; (b) low tungsten-high cobalt steeis; (c) high tungsten-low cobalt steels; $(d)$ high tungsten-high cobalt steels.

It is to be noted that these steels fall naturally into groups representing basic types to which varying proportions of cobalt, between about 2 and 5 per cent, have been added. However, the vanadium is generally found to be near the average values or low limits shown in Table I. A similar subdivision can be made for the special steels (Table I) containing either molybd?num or uranium, but since for the most part they are not yet of very great industrial importance and can in some cases at least be characterized as experimental heats, no additional comments concerning their compositions need be added.

The average carbon content of all major groups is between 0.65 and 0.70 per cent, but variations ordinarily encounterea are between 0.55 and 0.75 per cent. At times even higher proportions of carbon are found, but there is a decided tendency to keep this element above the specified low limit (o.55 per cent), as shown in Table 4 .

There appears to be a general tendency on the part of most manufacturers to keep the manganese content of all steels below about 0.25 per cent, but larger proportions are frequently found. This element, and carbon also, tend to increase the hardness of high-speed tool steels, but at the same time they make the tools more brittle. It was for this reason that Taylor recommended 
the manganese content be limited to about o.r 5 per cent. With respect to the effect of silicon in high-speed tool steels Taylor reported:

The statement has been published several times that high silicon tended toward higher cutting speeds in high-speed tools. In developing our patent we experimented quite thoroughly with this element and arrived at the conclusion that high silicon. tended toward slower cutting speeds, particularly when cutting the harder metals. In our patent, therefore, we recommended the low silicon, o.I5 per cent.

It is interesting to note that the average silicon content found in 66 lots of the modern steels is almost twice the value specified, and that a fair maximum for this element would be about 0.45 per cent, although one brand contained as much as o.8 per cent.

The high limits of phosphorus and sulphur are somewhat greater in these alloys than those ordinarily specified for structural steels and considerably in excess of proportions usually present in tool steels other than high-speed. Taylor found that high phosphorus and sulphur "were much less injurious to highspeed tools than they were to carbon tools," but claimed they still exerted a harmful influence and because of the high cost of production for the former, resulting from necessarily large additions of expensive alloying elements, recommended that only irons low in phosphorus and sulphur be used in their manufacture.

The present general tendency as regards chemical composition seems to include an increase in the permissible proportions of those elements, which may be termed "impurities," over amounts originally recommended by Taylor. However, certain brands will repeatedly contain higher proportions of manganese, silicon, phosphorus, or sulphur than others of the same type, a natural result of differences in raw materials and mill practice.

As previously stated, no marked differences in chromium are observed between different groups. More than half of all samples analyzed contain between 3 and 4 per cent, while the proportions present in over 85 per cent of these steels is between 3 and 4.5 per cent (Tabie 5). There are, of course, variations outside the specified limits, and certain brands may be considered to contain somewhat higher or lower chromium than others, but the majority of steels are within fairly close limits with respect to this element. The chromium in the modern steels is also lower than that in the best of Taylor's steels, and in this respect both English and American products are similar. However, the latter contain generally higher vanadium, as is shown in Table 6. 
The observed uniformity in chemical composition of steels containing large proportions of special elements is worthy of attention, as is also the fact that so many brands produced under widely different manufacturing conditions fall into such few groups. This condition must be considered as recognition of the importance of the chemical composition of high-speed tool steels, not alone as a single class within general limits, but from the standpoint of the different types in this class. It is therefore patent to examine the results of cutting tests of modern steels with the view to comparing types as well as brands, and both methods will be used in interpretation of the test data which follow.

It might be well at this point to call attention to the fact that metallurgists have often taken exception to the classification of commercial high-speed tool steels according to chemical composition, particularly when the tungsten content is made the basis of division. This is because the combined effects of small variations in the other elements present and differences in methods of production or treatment might affect the performance to as great a degree as changes in the proportions of tungsten. Despite such variations the majority of steels tested showed performance generally characteristic of the group in which they were placed, so that the chemical classification made and its application to discussion of the cutting tests appears justifiable.

\section{SEVERE BREAKDOWN TESTS OF 1 BY $1 / 2$ INCH ROUGH- ING TYPE OF LATHE TOOL.}

\section{DESCRIPTION OF TESTS.}

In Tables I I and I 2 are given results of three series of cutting tests made with $\mathrm{I}$ by $1 / 2$ inch lathe tools prepared from about 25 brands, and these are grouped according to the type compositions previously described. The first two were carried out in different shops with slightly different tool angles and cutting speeds, as shown in Table 7 , but with tools made from the same bars of any single brand. Heat treatments used in both series were carried out at one time with the same equipment and operators under the instructions of the manufacturers' representatives.

The third set of tests consisted of some of the tools in the first series after they had been thoroughly annealed, re-treated, and ground, together with tools from different lots of the same brands or types not originally represented. Annealing was carried out $11511^{\circ}-23-2$ 
by heating to $\mathrm{I}, 550^{\circ} \mathrm{F}$. and slowly cooling in a furnance to room temperature, while the final heat treatments were not necessarily those recommended by the manufacturer but were chosen with the idea of obtaining the best tool performance for each type. These treatments were carried out by different operators in two shops which had not participated in tests Nos. I and 2. Thus the three sets of tests should furnish a definite idea regarding the possibility of reproducing results in a severe breakdown test with roughing tools, particularly with respect to brand or type comparisons.

(a) Tool Form.-The form of tool selected for all tests was that known as Sellers No. 30 and is commonly employed for heavy duty roughing work. Its angles are $6^{\circ}$ clearance, $8^{\circ}$ back slope, and $14^{\circ}$ side slope, while the radius of the nose was made $\frac{3}{16}$ inch. The edge of the tool between this arc and its full width was straight and met the surface of the bar about I inch from the end. This form was adhered to in tests Nos. 2 and 3 , but in test No. I the angles were accidently modified to $6^{\circ}$ clearance, $7,2^{\circ}$ back slope, and $12^{\circ}$ side slope.

(b) HEAT TREATMENT.-After grinding roughly to the described form the tools were warmed on top or in front of the preheating furnance to about $30^{\circ} \mathrm{F}$., preheated in semimuffle or muffle type furnaces, subsequently heated to the quenching temperature, and quenched in either sperm or Houghton's No. 2 soluble quenching oil. They were then tempered at temperatures shown in Tables I I and I 2 .

The tools were next carefully ground wet in an automatic machine in order that they would all be of the same form. In addition to grinding, the nose, top, and bottom surfaces were ground on those tools tested in the third series. This was made necessary on account of slight distortion, which resulted from hardening the entire length, so that both ends of each bar could be tested instead of heating only one end, as was the case with tools used in tests Nos. I and 2.

High heat furnace temperatures were controlled by platinum thermocouples connected to potentiometers, while base metal couples and either direct-reading galvanometers calibrated just prior to test or potentiometers were used in maintaining preheating and tempering temperatures. For the few tools subjected to very low-temperature tempering calibrated thermometers were used. Preheating was carried out in semimuffle type furnaces, except for a few tools used in test No. 3, when electrically heated 
muffles were used. The time for which tools were held in the highheat furnace was carefully controlled in all cases. The relatively large variations and generally longer periods in test No. 3 were due principally to the use of several furnaces of varying size and construction necessitated by breakdown of the first unit.

The "sweating operation" in the hardening of high-speed tool steels is a most important feature, and the rapidity with which the desired effect can be produced for steel of nearly constant mass depends largely on the heating units. If the steel is held too long at high temperatures in the neighborhood of or above $2,400^{\circ} \mathrm{F}$. excessive oxidation and considerable decarburization result, and, in addition, the metal becomes "mushy," so that it readily breaks when squeezed by tongs (Fig. I). The time for which tools were held in the high-heat furnace was therefore longer in those cases in which units of relatively small thermal capacity were employed,

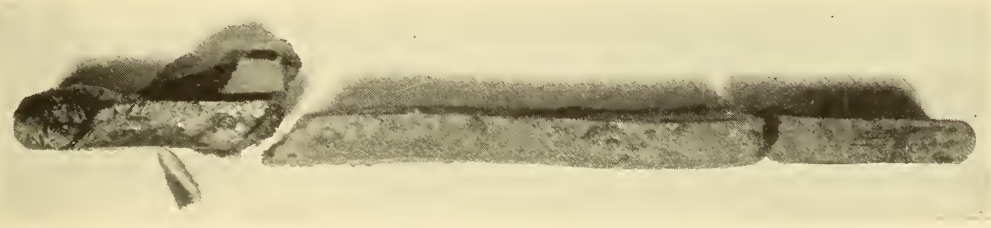

FIG. I.-Partially melted tool left too long in the high heat furnace at $2,4 I 5^{\circ} \mathrm{F}$.

Tool broke where held by tongs in attempting removal from furnace.

but in making use of any furnace preliminary tests were first made to determine what was considered to be the proper time of heating. For tests Nos. I and 2 oil-fired semimuffle furnaces were employed, while a similar type heated by gas or a carbon plate resistance furnace was used in hardening tools tested in the third series.

(c) Test Procedure.-Heavy duty motor-driven engine lathes of a capacity somewhat in excess of that actually required for the work to be performed were used in all tests. That employed in tests Nos. I and 3 is shown in Figure 2. Speed control of the motor was such as to permit obtaining the desired surface speed of the test $\log$ within about +5 and - o per cent and all tests were run dry. The tools varied in length from 8 to I I inches, and the holder in which they were used was I 5 inches long. This consisted of two carefully machined $U$-shaped sections with the bottom of the groove square, $\frac{17}{32}$ inch wide, and $3 / 8$ inch deep. One section was placed above and the other below the tool, and both were held in alignment by two dowel pins at each end. The holder 
with the tool in place was clamped in the four-bolt tool post shown in Figure 2.

Cutting was done on test logs of about ${ }_{5}$ inches diameter and 8 feet long, of forged and heat treated 3 per cent nickel steel, such as is in wide commercial use for heavy forgings. One to two inches were removed from the diameter after heat treatment, and testing was stopped when the $\log$ had been cut down to 8 inches. The chemical and physical characteristics of these forgings are shown in Table 8.

It will be noted that the test logs used in the three series of tests are quite similar and uniform throughout, as far as may be judged by the tensile properties and hardness. Without doubt, hovever, variations in machinability exist, so that one tool of each brand was tested before the second tools were used. The latter were then tested in order before the third tool of each brand was tried. Such regulation of the sequence of testing almost certainly renders physical variations in the test logs negligible in their effect upon results obtained. At least this procedure goes as far toward obtaining uniformity in large masses of metal as can reasonably be expected. The feed used in all tests was 0.045 inch per revolution and the depth of cut $\frac{3}{16}$ inch. The desired cutting speed, determined on the bottom of cut, was 67 feet per minute in test No. I, 6I feet per minute in No. 2, and 60 feet per minute in test No. 3 (see Table 7).

Before starting any test great care was taken to remove the glazed surface of the log remaining after the breakdown of the previous tool and also any particles of the tool which may have been ground into the surface of the metal being cut. The tool to be tested was then forced against one side of the $U$-shaped grooves in the holder and set to project beyond the end of it by $3 / 4$ inch. The holder was next clamped in the tool post, so that the side of the tool was at right angles to the log surface, the top level, and the end of the nose on dead center. After adjusting the speed of the lathe to give the desired surface speed to the log the tool was fed in by hand (having previously been adjusted to proper depth) until it took a full cut, the automatic feed was then thrown in, and the time observed. Breakdown was sharp in all cases and left no doubt as to the time of any run. 'The tools of the first set were tested on $\operatorname{logs}$ I and 2, those of the second on $\log 3$, and those of the third on $\log 2$. 


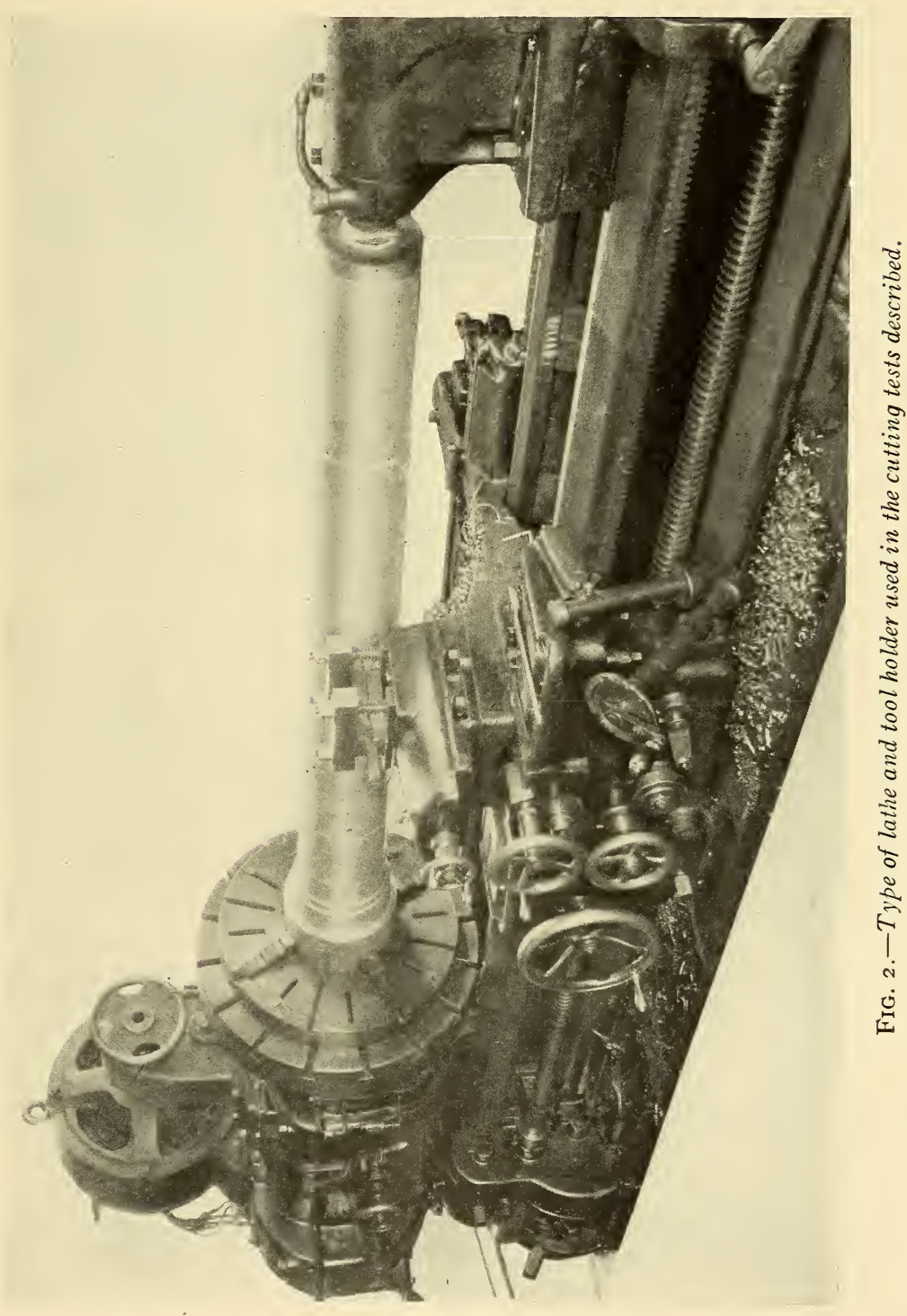




\section{DISCUSSION OF RESULTS.}

(a) Brand Comparisons.-A number of interesting and instructive features are revealed in the results of these tests. The average time that tools of any one brand will cut is greater in some instances after the first grind than the regrind. For certain brands the reverse is found to be true, while the two averages obtained are often practically the same, but none of these three conditions can be considered characteristic of any one type of steel.

Large differences are observed in performance of individual tools made from one bar of steel or in testing both ends of a short tool which has been hardened over its entire length (Table I2). It is therefore necessary to test a relatively large number of tools and also to repeat the test after they have been reground at least once if results or comparisons of value are to be obtained.

Various brands in the same group show differences in performance which can not be ascribed solely to variations in chemical composition or heat treatment (for example, steels $\mathrm{J}$ and $\mathrm{O}$ ), but in most cases comparable results were obtained. However, the order of value of different brands of nearly similar performance may be entirely changed by a modification in test, as shown in Table 9, or by substitution of tools from several lots of the same steels for those originally tested, and it is therefore necessary to use care in making comparisons. Severe breakdown tests, such as those described, will show markedly inferior tools, whether this inferiority is due to the quality of the steel, improper heat treatment, a combination of these or other causes, but the grading of brands of nearly similar performance, often made use of in the purchase of high-speed tool steels, is not justified and if made is of no value. This distinction in interpretation of results has usually been overlooked, or at least not sufficiently emphasized by those who have carried out and made use of comparative tests of a similar nature.

(b) Group Comparisons.-In group comparisons similar precautions are to be observed, but some significant variations in the performance of different types are evident, as shown in Table io, in which the highest average endurance in each of the three series of lathe tests is rated as roo per cent and the remaining groups given their respective valuations. There is no doubt that the low tungsten-high vanadium and cobalt steels as groups are the best. An attempt to differentiate between these, based on the results ob- 
tained, would be of little value, as their relative positions vary in the several tests without very marked differences in performance.

Medium and high tungsten steels and those containing molybdenum or uranium show comparable endurance which may be rated as roughly 60 per cent of that of the low tungsten-high vanadium steels. A tungstenless high-speed tool steel introduced for comparative purposes has a rating of approximately 30 per cent.

The relatively poor showing of the high tungsten steels is significant, especially since they represent the most popular type now manufactured in this country. Many of those tested are wellknown brands produced by manufacturers who are known to take all reasonable precautions to insure the quality of their product, so that the observed inferiority would not naturally be ascribed to generally poor quality of steel, but rather to the fact that the average endurance of this group is less than that of the low tungsten-high vanadium steels, or that the heat treatments employed were not the best that could be used. Probably both are contributary causes.

The fact that steels containing one-fourth per cent uranium did not develop exceptional performance is in agreement with results obtained by Langhammer ${ }^{5}$ under entirely different and more moderate working conditions and, likewise with the opinion held by Mathews, ${ }^{6}$ who recently stated that "so far as our experience goes we have been unable to see that it (uranium) confers any specific benefit."

An interesting feature developed in the first two sets of tests is that a change in working conditions, including small variations in tool angles but mainly a decrease in cutting speed from 67 to $6 \mathrm{I}$ feet per minute, produced a much larger increase in the average endurance of steels containing cobalt or special elements than in the plain chromium-tungsten-vanadium steels (basic types). In this respect the cobalt steels show greater variation than those containing molybdenum or uranium, and in one case, that of brand $\mathrm{S}$, as much as about 90 per cent increase.

(c) Character of Chips Produced and Failure of The Tools.-Some quite definite and more or less regular variations in the character of chips produced during progress of the lathe tests were observed. Almost without exception a long "ribbon" of steel was obtained at the start. The first break would, of

\footnotetext{
${ }^{5}$ A. J. Langhammer, "A comparative test upon high-speed steels," Chem. and Met. Eng., 22, pp. 829, 889 , 939 , and 969 .

${ }^{6}$ J. A. Mathews, "MIodern high-speed steel," Proc. Am. Soc. Test. MIat., 19, part 2, p. I4I.
} 
course, be largely dependent upon the character of support accorded the metal in its unguided travel, but if held by tongs and pulled away from the test lathe an unbroken metal strip, often several hundred feet long, resulted (Fig. 3). Shorter and shorter chips were produced as the tool continued to cut, and these varied in length from about half a foot at the beginning of what may be called the second stage to a fraction of an inch just before

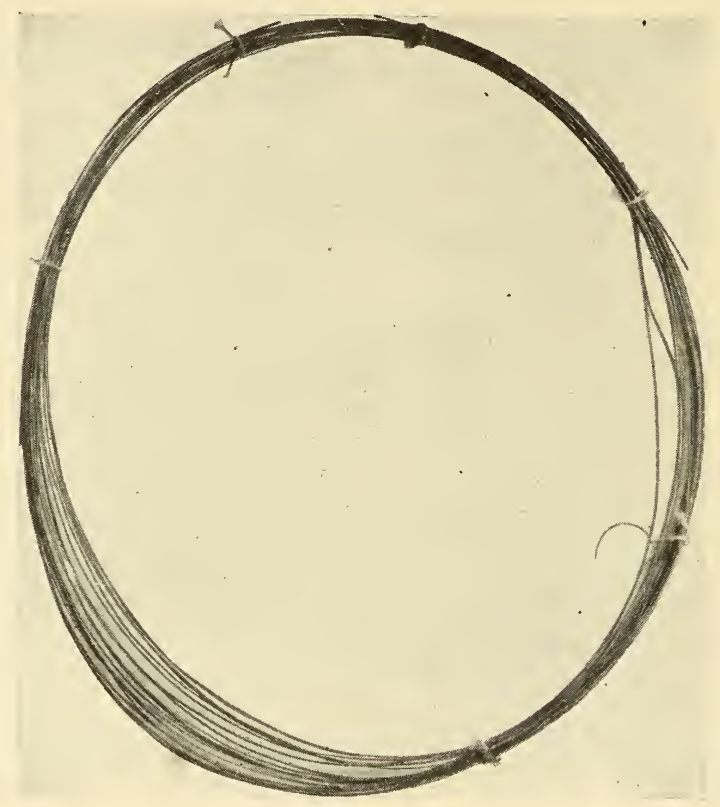

Fig. 3.-Typical "ribbon" of metal often obtained at the beginning of cut in severe breakdown test, when suitably supported and guided away from test lathe.

Ribbon shown is approximately 300 feet long with a cross section of $\frac{3}{16}$ by 0.045 inch which was produced at 60 feet per minute. The several broken ends shown resulted from coiling preparatory to taking the photograph.

failure. These characteristics were so generally representative that they became a rough indication of the quality of the tool soon after the beginning of the cut.

Progressive decrease in length of chips is undoubtedly largely caused by a gradual change in the most effective portion of the top surface of the tool, resulting from abrasive action of the metal being cut. A groove or "gutter" is worn" near the nose and forces the chip to curl more and more sharply as the wear increases, and because of the cyclic variation in pressure ${ }^{7}$ and the fact that

7 See footnote I with particular reference to data given in folder I 2. 
the chip is already highly stressed the ribbon breaks into small sections instead of passing freely over the tool at approximately its original top angles. The wear on the entering side near the nose is also an important contributing factor particularly near the end of the cut, and both effects are shown in Figure 4.

Breakdown is concommitant with the production of a "glaze" on the test $\log$ (Fig. 5). At the moment of failure, which generally occurs suddenly, the dimensions of the chip decrease both in direction of the feed and depth of cut. This is probably caused by "springing" of the tool in the holder and is due to greatly increased pressure in all directions resulting from the "dulling" or rubbing away of the nose. If the tool is withdrawn from the test $\log$ at the first signs of failure, the last thin chip produced

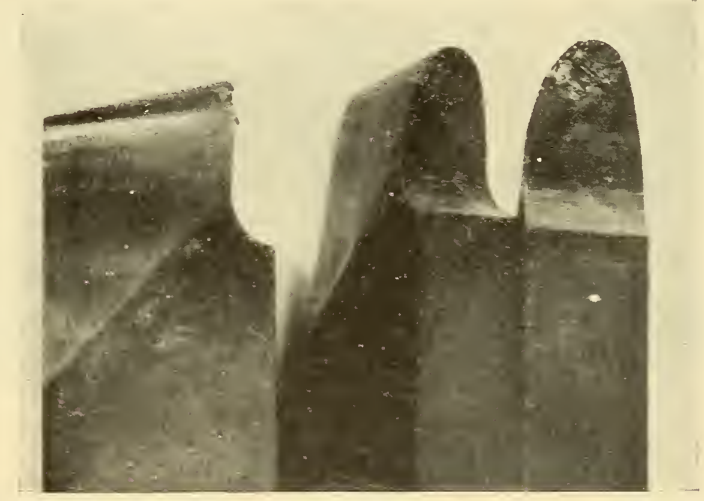

FIG. 4.-Typical failures of roughing lathe tools in severe breakdown tests, $X$ about $\mathrm{I} / 2$.

Note the rubbing off of the nose and "gutter" or groove worn on the top surface of the tools.

will often "freeze" to the nose, as shown in Figure 6, thus giving concrete qualitative evidence of the high pressure and temperature existing at the moment.

(d) Power Consumption.-Thus far discussion of test results and comparisons have been on the basis of the time required to produce failure in tools working under definite cutting speeds, feeds, depth of cut, etc. Certain groups were shown to have repeatedly better performance than others, despite certain small but definite changes in test conditions, but the question which almost immediately arises is whether or not more power is consumed by any one set of steels over others in cutting metal at a giren rate for equal times. Electric power is measured in kilowatt hours and that consumed in equal time intervals is proportional to the average kilowatts (energy) during the interval, $11511^{\circ}-23-3$ 
which are derived from ammeter and voltmeter readings or shown by wattmeters.

The values given in Table I 3 for tools used in test No. I show that the power consumed by various brands and groups is prac-

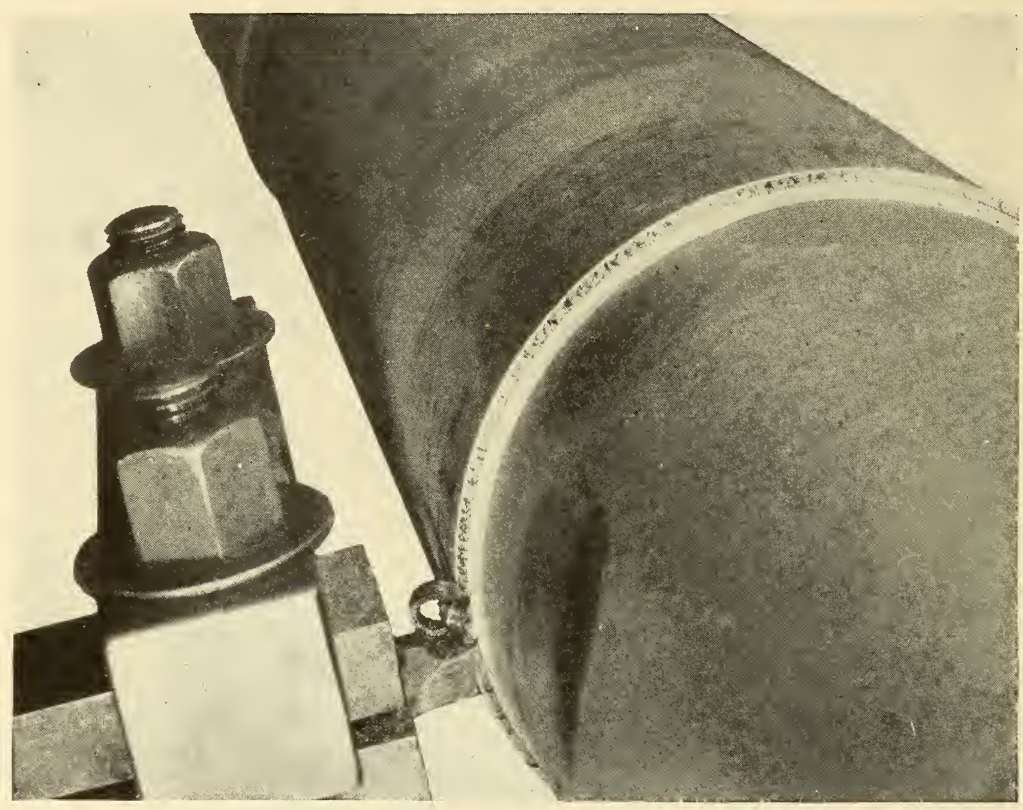

Fig. 5.-Failure of a tool under test.

Shows "glaze" produced under test.

tically the same in all cases. Differences observed between individual tools are often greater than variations between different brands, but are not large and can not be considered to have any

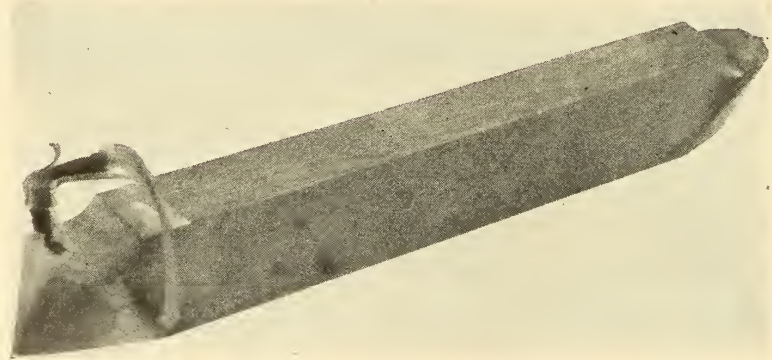

FIG. 6.- "Freezing" of the last thin chip to the nose of tool.

special significance. Thus, the various types of high-speed tool steels remove the same amounts of metal at equal rates with practically the same power consumption, but some have greater endurance than others. 


\section{MODERATE BREAKDOWN TESTS OF $1 \mathrm{BY} 1 / 2$ INCH ROUGHING TYPE OF LATHE TOOL.}

It was pointed out at the beginning of this report that high tungsten-low vanadium high-speed tool steels are the most popular type produced at the present time, and subsequently it was shown that the endurance of this group in certain severe breakdown tests was generally much less than that of the cobalt or low tungsten-high vanadium steels.

While the conditions under which these tests were made may represent those obtaining in actual practice, it is true that a large part of the work for which high-speed tool steels are used in various shops is carried out under more moderate working conditions which do not produce the high frictional temperatures obtained in the authors' tests. It is therefore patent to compare the various groups when subjected to more moderate service.

Four tools to represent each of the three most important groups were chosen from the various brands used in test No. 3 , as shown in Table I4. In this selection of tools already tested an effort was made to obtain groups of four or five having nearly the same average performances as those obtained in the third set of tests. All tools were ground to form in exactly the same manner as in the previous experiments, and the tests carried out represent the third and fourth grinds. They were made with the same test $\log$, tool angles, cutting speed, and depth of cut, but with approximately three-quarters of the feed used in test No. 3 .

The relatively poor endurance of the high tungsten-low vanadium steels in the severe tests is not observed under the more moderate conditions of service in test No. 4, a feature which assists in explaining the popularity of the high tungsten type for general roughing work. However, insufficient tests have been made to determine whether the performance of the high tungsten steels is equal or better than that of the low tungsten-high vanadium type under the working conditions used.

\section{LATHE TESTS OF SMALL TOOLS.}

Breakdown tests of large tools, such as have been described in previous sections of this report, are very expensive to make because they require large masses of uniform metal to be cut, heavy equipment, and considerable time. The limitations in interpretation of data obtained, as already described, make it questionable whether information derived from repeating this type of test 
with various steels is commensurate with the cost (except in special instances), especially since comparable performance is observed in the majority of steels in any one group. At least the variation in performance of the various steels (with some exceptions) is not more than would be expected from different lots of the same brand supplied throughout a period of several months. If as much information or satisfactory comparisons could be obtained with smaller tools, the cost of tests would be materially reduced.

Accordingly, one large tool from each of the low tungsten, high tungsten, and cobalt groups was annealed, cut into smaller tools, heat treated, ground, and tested in a manner similar to that already described for the large tools. The dimensions of tool chosen were half those used in the first four sets of tests-namely, $\mathrm{I} / 2$ by $1 / 4$ inch-and the radius of the nose was made $\frac{3}{32}$ inch instead of $\frac{3}{16}$ inch. Tool angles, speed, feed, and depth of cut were exactly the same as those used in test No. 4, as was also the test log. On account of the sharper nose required in the small tools and their size these test conditions, which were considered to be only moderately severe in the case of the large tools, may be considered as somewhat more so for the small tools, but probably not equivalent to the severe working conditions obtaining in the first three sets of tests. Results obtained are given in Table 15 .

As in the severe tests of large tools the low tungsten-high vanadium steel has better endurance than the high tungsten type, but there is not such a large difference in performance as was observed in the large tool tests. The magnitude of the observed effects can not be compared, as the change in size of tools is not the only variable introduced. The important feature is that the small tool tests, carried out under severe working conditions, once more show superiority of the low tungsten-high vanadium steel. The heat treatment of the high tungsten-cobalt steel was inadvertently changed and a low hardening temperature used which without doubt accounts for the relatively poor performance of this steel. It will also be noted that the variations in the performance of individual tools is, in general, no greater when testing the small tool bits than when using the large tools. However, the same precautions in making tests and in interpretation of results must be observed in both cases. The results obtained, therefore, indicate that when small tool tests are carefully carried out the sensitivity is such as to yield results of some value. 
A most interesting feature is revealed in comparison of the performance of $\frac{1}{2} 2$ by $1 / 4$ inch and $\mathrm{I}$ by $\mathrm{I} / 2$ inch tools when removing metal from the same test log under the same cutting speed, feed, depth of cut, etc. With the exception of the $1 / 2$ by $1 / 4$ inch tools prepared from the cobalt steel, which were hardened at a low temperature, the small tools removed more metal than the large ones before failure.

There are a number of variables in the two sets of tests which, as previously mentioned, make inadvisable detailed comparisons of the values reported, but it is doubtful whether any of the readily recognizable differences in these two sets of tests adequately account for this result, and the authors do not at the present time offer any explanation.

\section{MISCELLANEOUS TESTS.}

\section{SECONDARY HARDNESS AND HEAT TREATMENT.}

Examination of Table II, in which are given the heat treatments recommended by different manufacturers, shows that these vary widely for brands of the same type composition. High-heat furnace temperatures from 2,300 to $2,500^{\circ} \mathrm{F}$. and tempering temperatures between $45^{\circ}$ and $\mathrm{I}, \mathrm{IOO}^{\circ}, \mathrm{F}$. are found and indicate that there is not yet complete agreement as to the most suitable treatments to use under given working conditions.

The lathe tests made were primarily comparisons of brands or groups of steel, and it is therefore not possible to consider in detail the effects of variations in heat treatment upon the performance of different type compositions. However, certain indications were obtained which made it desirable to carry out such special tests as determinations of secondary hardness, character of fracture, etc., and the results are summarized in the following paragraphs:

I. High tungsten steels withstand high hardening temperatures of approximately $2,400^{\circ} \mathrm{F}$. better than do the medium or low tungsten steels. An indication of this difference is given by Groups B and C, Figure 7, in which is shown the surface condition of many of the tools used in test No. 3 .

2. Low tungsten-high vanadium steels are more sensitive to heat treatment, especially with respect to variations in hardening temperatures between $2, \mathrm{I} 5 \mathrm{O}$ and $2,400^{\circ} \mathrm{F}$., than the high tungstenlow vanadium type. This is shown by the more rapid coarsening of structure observed in examination of fractures and by varia- 
tions in hardness under varying treatments (Figs. 8 to I 2 , inclusive). Not only are the latter changes smaller in the high tungsten steels for variations in hardening temperatures but they are also less for changes in tempering. However, the addition of

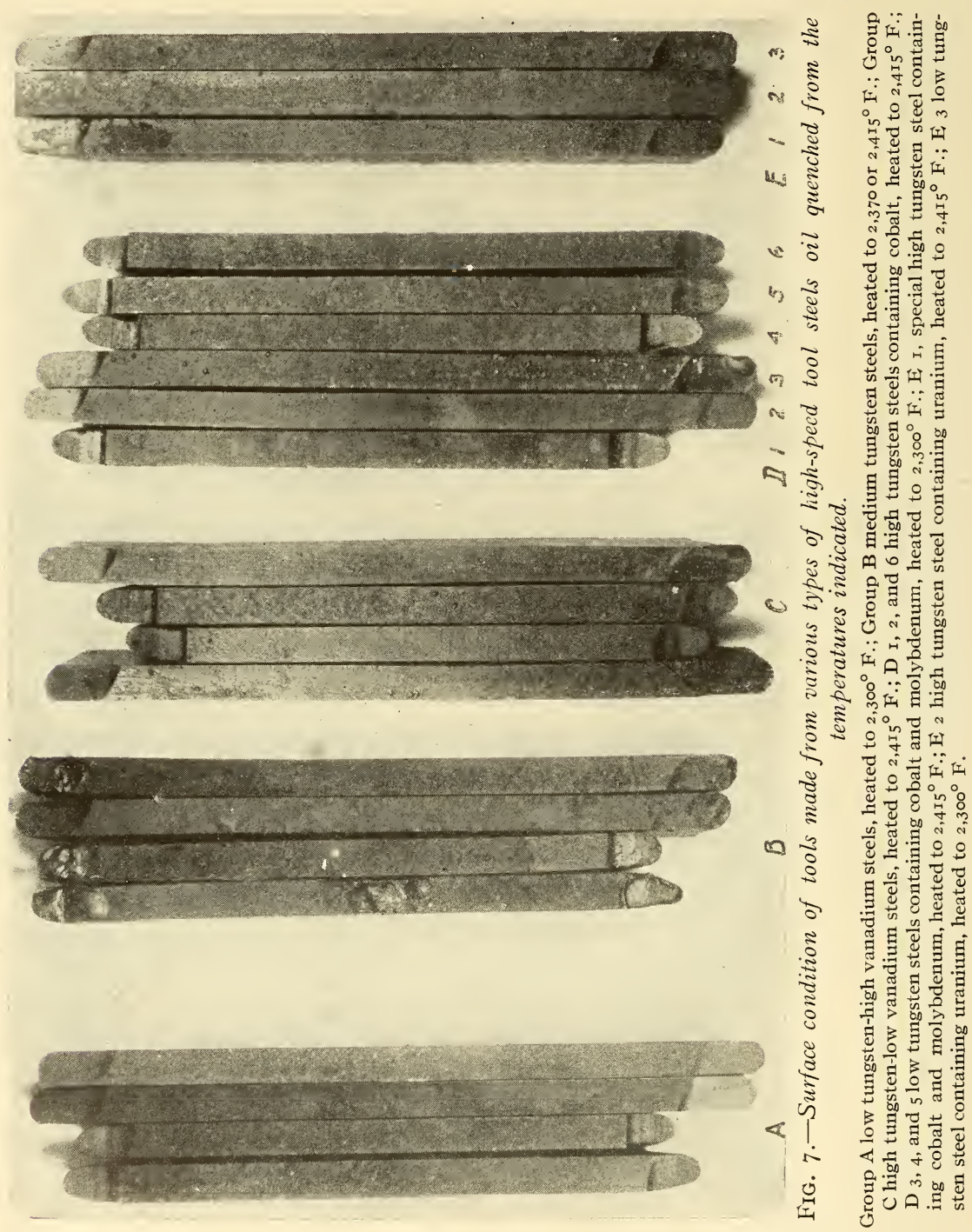

cobalt to low tungsten steels appears to produce a more stable product.

This does not mean that a given change in high heat temperature, for example, will affect the performance of low tungsten steels to a greater- degree than that of the high tungsten-low 
vanadium type. This might, however, be true under certain working conditions. The probable relation existing between heat treatment, hardness, and cutting qualities of high-speed tool steels has recently been summarized in a very clear and concise manner by Mathews, ${ }^{8}$ as follows:

The Iower the temperature at which the initial hardening is done the lower will be the temperature at which the rehardening occurs on tempering, and presumably the sooner a tool so treated would fail in severe cutting where the frictional temperature

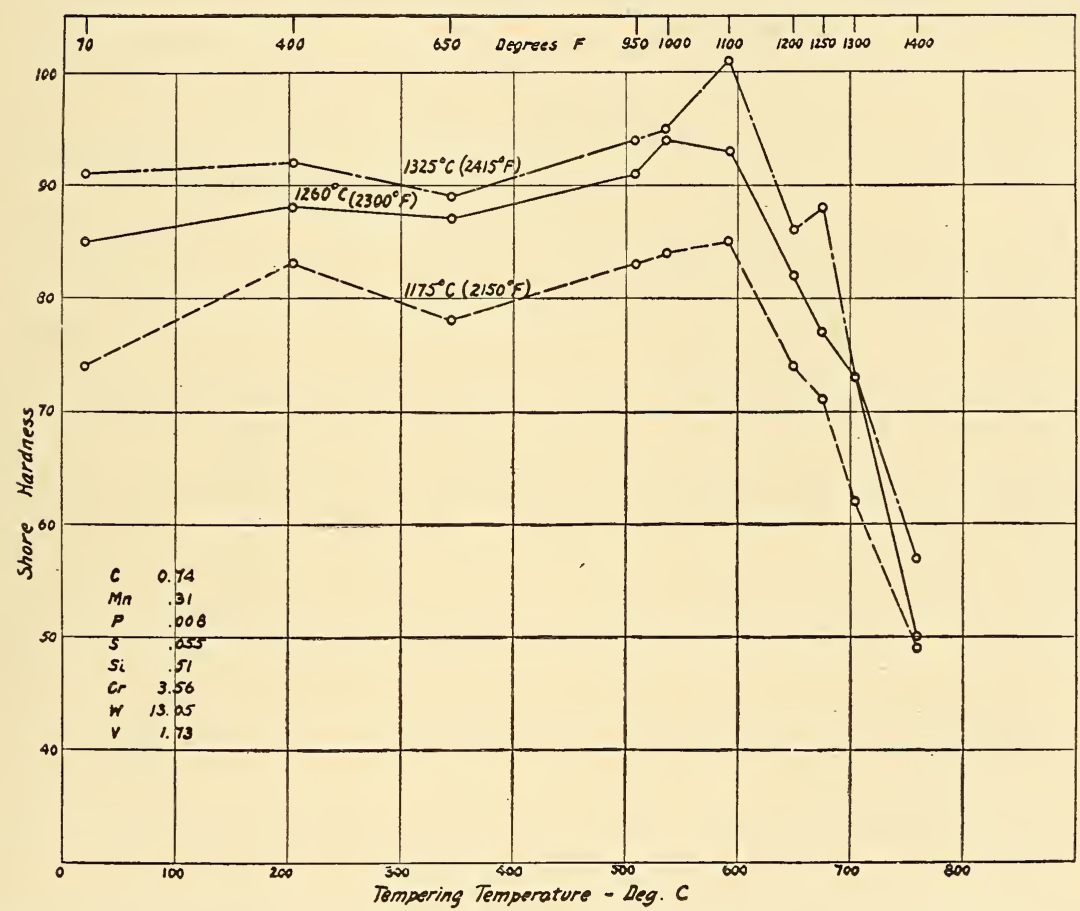

FIG. 8.-Rehardening upon tempering of low tungsten-high vanadium high-speed tool steel, first oil quenched from various temperatures.

was high. When the temperature in cutting is not extremely high, we can not conclude that the steel would fail sooner than one with a higher rehardening temperature. In such cases, in my opinion, physical or mineralogical hardness plays an important part as distinguished from red hardness, but where the cutting conditions are severe it would appear logical that the higher the temperature of red hardening the longer the endurance of the tools.

Thus the various types of steel which showed marked differences in performance in severe service likewise show differences in their behavior under heat treatment and in physical properties which probably are of importance under more moderate working conditions.

${ }^{8}$ See footnote 6 . 


\section{MICROSCOPIC EXAMINATION AND FRACTURES.}

Mention has already been made of large differences in performance of tools made from the same bar of steel. While the reasons are often obscure on account of the large number of variables readily introduced into breakdown tests, it is frequently possible to pick out the principal causes by use of the microscope and examination of fractures. A few illustrations taken from tools used in the cutting tests previously described are contained in Figures 13 to 17 , inclusive.

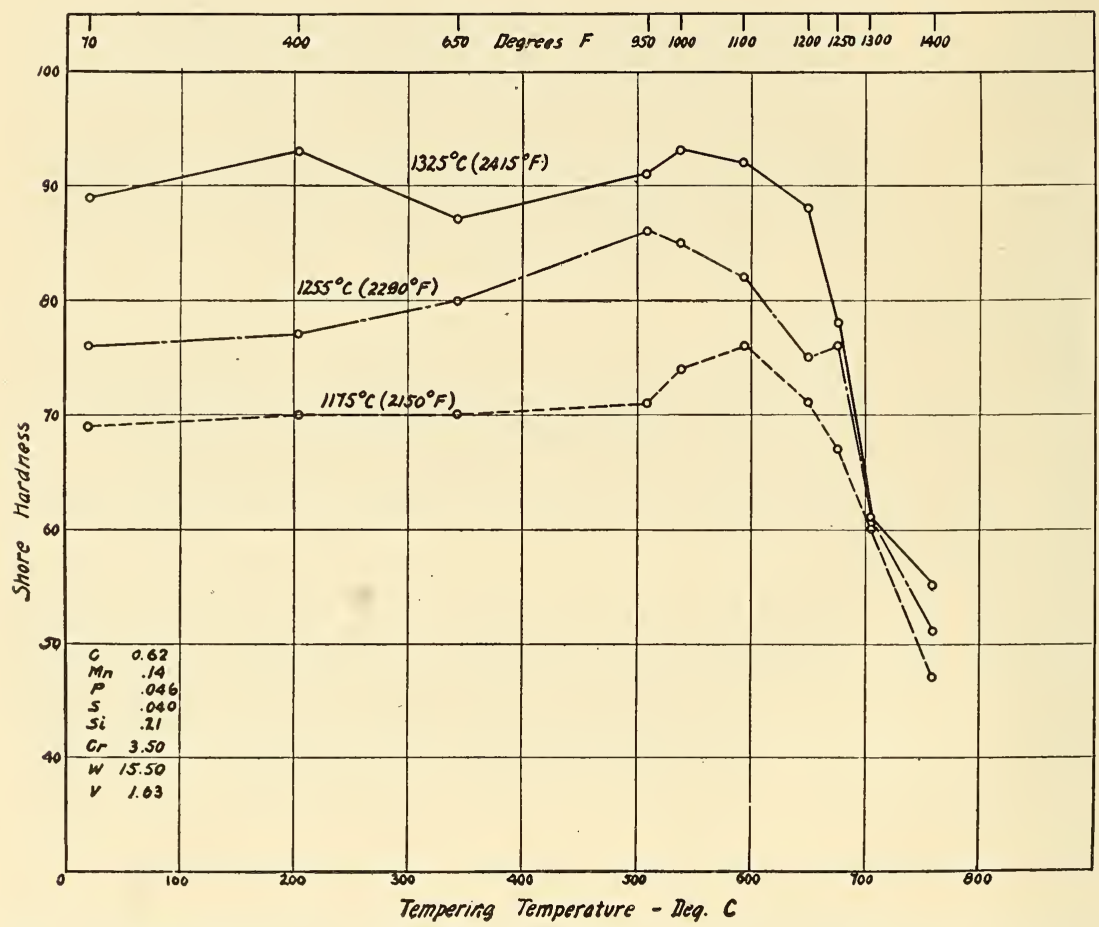

FiG. 9.-Rehardening upon tempering of medium tungsten high-speed tool steel, first oil quenched from various temperatures.

The appearance of fractures and structures may be very different for steels of similar chemical composition subjected to the same heat treatments, whether comparisons are made between tools from the same bar of steel or from different lots or brands. For example, two of the high tungsten-low vanadiam steels have moderately coarse fractures, while that of steel $\mathrm{X}$, of similar composition, is the finest of all examples contained in Figure $\mathrm{r}_{3}$. The microstructure of this steel is shown in Figure $5_{5} a$, and attention is called to the extremely fine grain size and uniformly distributed 
tungstides, carbides, etc., in contrast with the segregation shown in Figures ${ }_{5} c$ and $16 a$. Such differences in structure originated during the progress of manufacture and can not be eliminated by heat treatment. Steels like those shown in Figures I $_{5} c$ and r $6 a$ often show "fish-scale" fractures similar to that reproduced in Figure I4, and in cutting tests generally poor and erratic results are obtained.

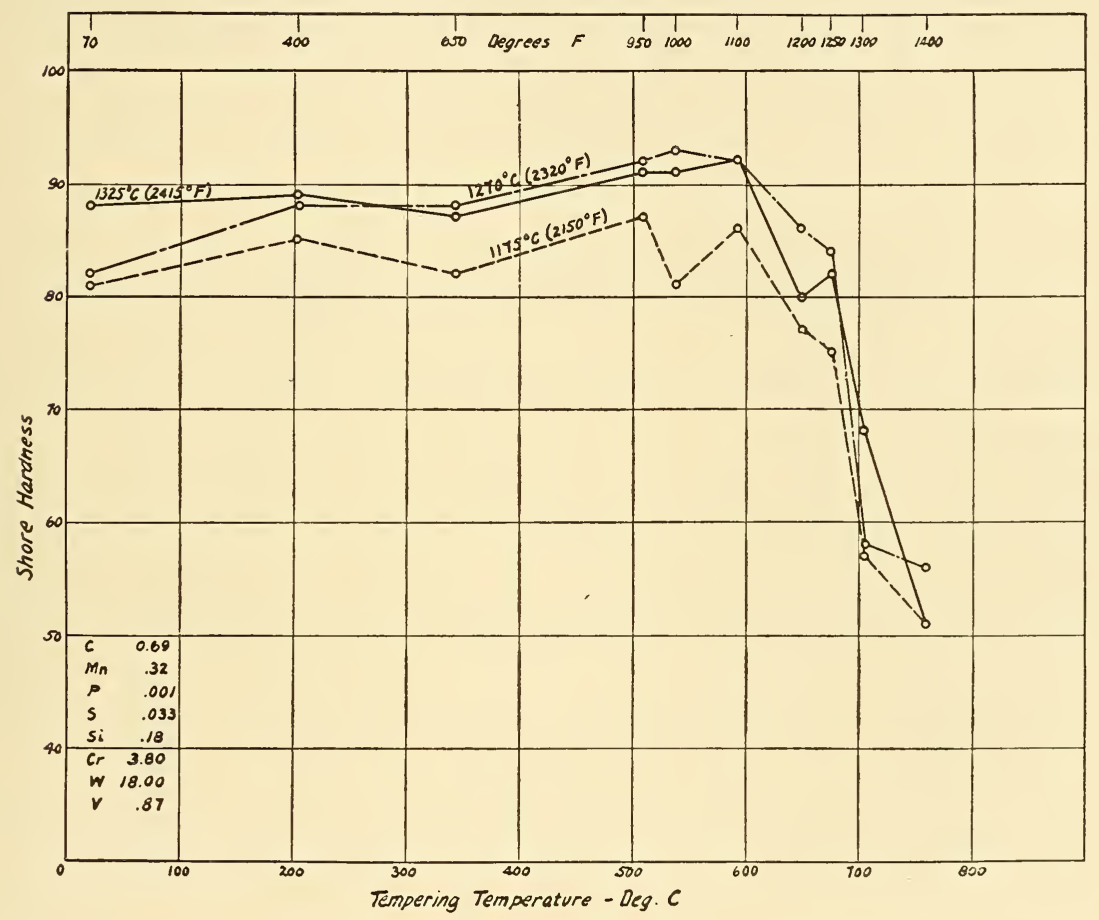

FIG. IO.-Rehardening upon tempering of high tungsten-low vanadium high-speed tool steel, first oil quenched from various temperatures.

\section{GENERAL DISCUSSION.}

\section{COMPOSITION v. QUALITY OF STEEL AND HEAT TREATMENT.}

Considerable emphasis has been placed on the chemical composition of high-speed tool steels, though mention has likewise been made of the necessity of high-grade raw materials, good melting practice, and care in fabrication in producing alloys of superior performance.

Clean, sound metal free from impurities and excessive segregation, including "stringers" of carbides, tungstides, etc., is essential, and it is true that the behavior of two lots of practically 
identical composition and heat treatment may be quite different in service because of variations in the quality of the steel. However, its composition is likewise of importance and should not be disregarded. If it is not within certain limits, the steel can not have satisfactory performance. On the other hand, the mere fact that the metal comes within the ordinary limits of chemical composition does not insure its behavior in service.

The practice of purchasing and using high-speed tool steels solely by name is not the ideal method, for there is always the possibility

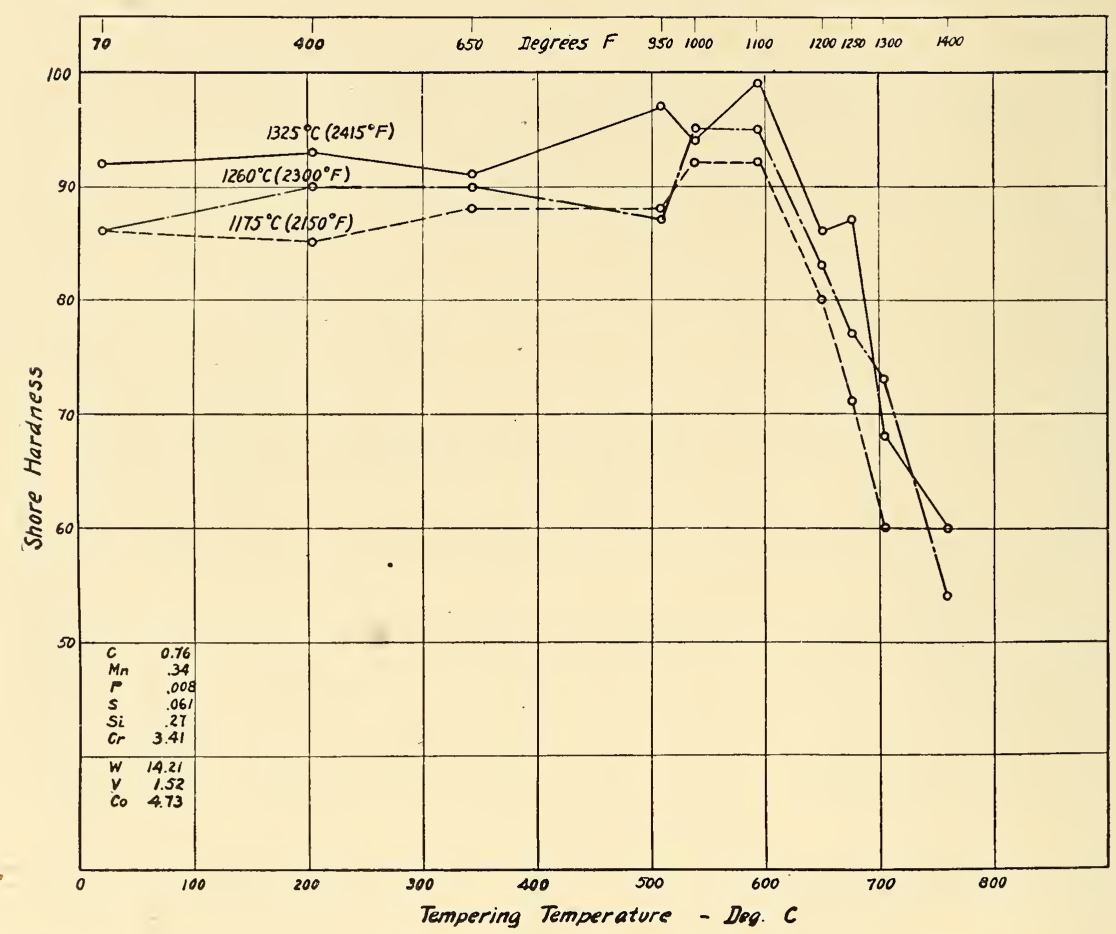

FIG. II.-Rehardening upon tempering of medium-low tungsten high-speed tool steel containing cobalt, first oil quenched from various temperatures.

of change of type resulting from a variety of causes. This may result in decreased performance with rise in tool costs or require a modification in treatment for maintaining comparable service. While such conditions may not often be encountered, they are, nevertheless, observed and therefore are of importance. In an instance recently brought to the attention of one of the authors two organizations were using the same brand of steel. In the first case low tungsten-high vanadium steel was regularly supplied while the second plant reported this brand to be the high tungsten- 
low vanadium type. In view of the test data previously described no further comments regarding such a condition need be made.

A lot of a well-known brand, normally of the high tungsten type containing about I per cent vanadium, recently gave one organization considerable trouble and had only about one-fifth its ordinary endurance. Examination developed the fact that less than 0.2 per cent vanadium was present. This material was undoubtedly shipped in error, and no difficulty would be encountered in obtaining replacement, but the cost in time and labor

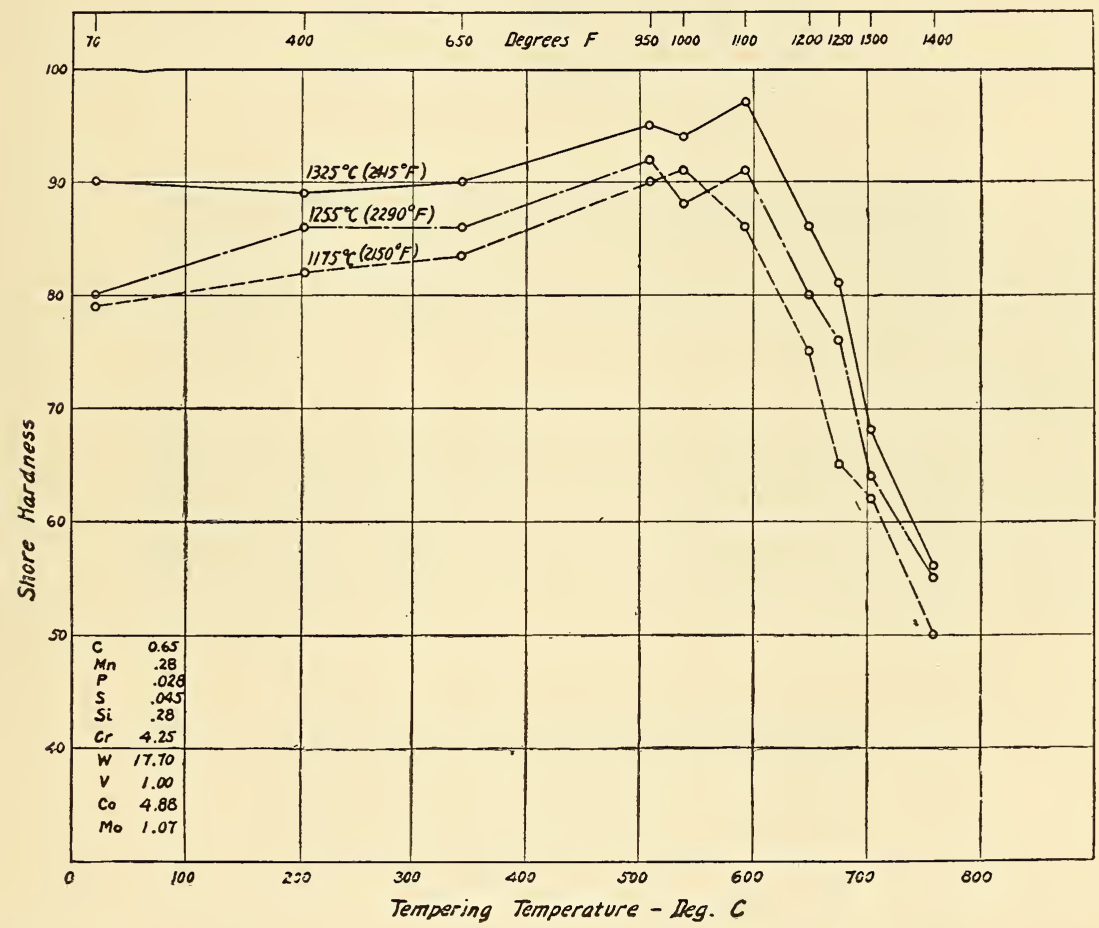

FIG. I2.-Rehardening upon tempering of high tungsten high-speed tool steel containing cobalt and molybdenum, first oil quenched from various temperatures.

ot such errors to the many shops not ordinarily checking the composition of high-speed tool steels but buying and using them solely by name is of considerable magnitude. Having secured steel of satisfactory quality and of suitable composition, great care is required in heat treatment. Methods including accurate temperature control but disregard of the time factor are not satisfactory.

When it is considered that in many cases lathe tools are placed in heat-treatment furnaces which are maintained at temperatures 

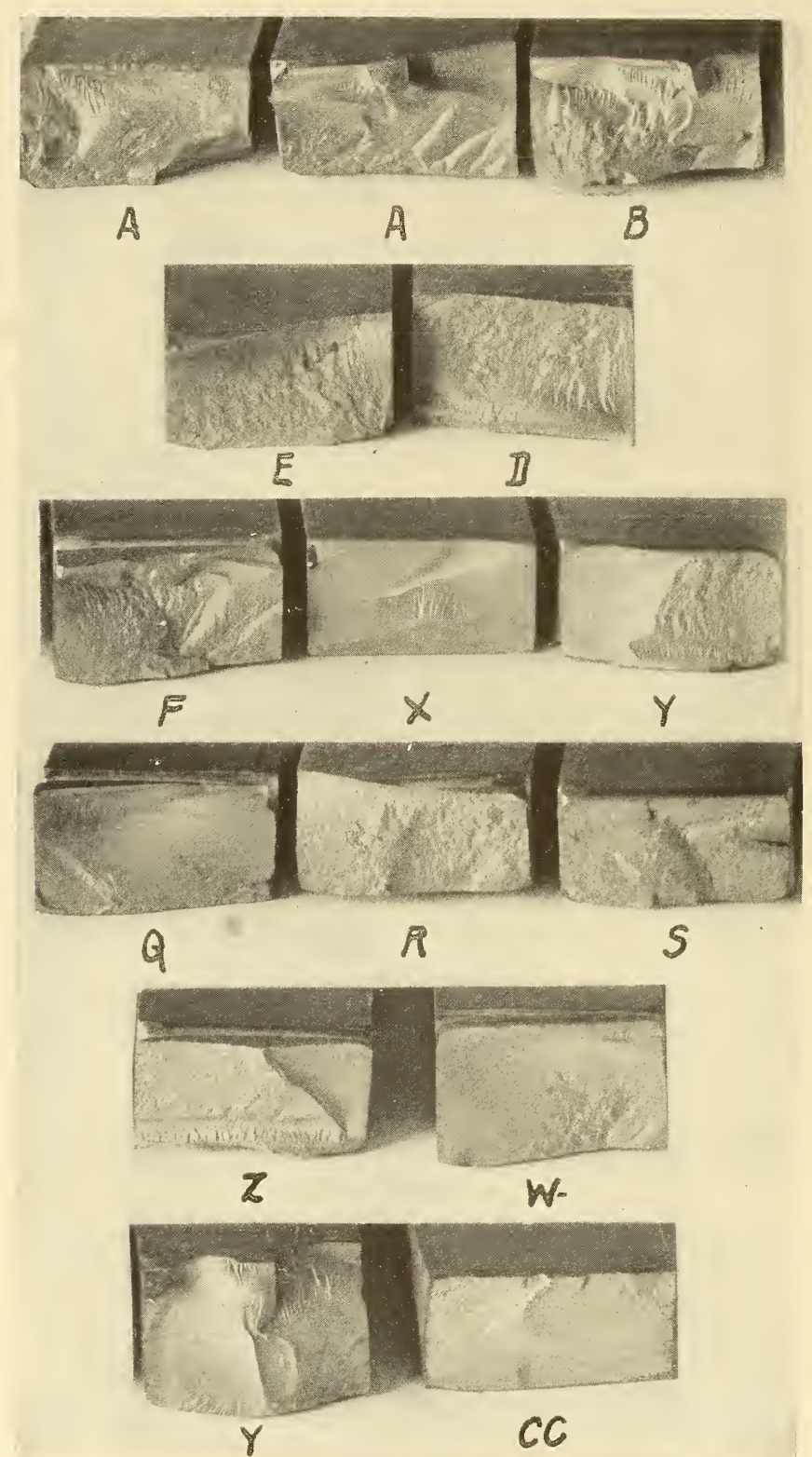

FIG. I3.-Fractures of some of the lathe tools subjected to breakdown tests $\times$ about $1 / 2$.

Tools shown are those hardened over their entire length and used in test No. 3 . Letters shown represent the various brands. 
sufficient to melt the steel (see Figs. I $5 b$, I $6 a$ and $b$, and I $_{7}$ ), and that, therefore, the time element is largely depended upon in correctly carrying out the hardening operation, it is not difficult to understand why erratic and unsatisfactory results are so often produced.

\section{BREAKDOWN TESTS FOR THE PURCHASE OF HIGH-SPEED TOOL STEELS.}

The chemical composition, quality of metal, and heat treatment are three most important factors to be considered in the purchase of high-speed tool steels. The advice of manufacturers can readily be obtained regarding available types best suited for definite service or, if desired, comparative cutting tests can be made. No difficulties should then be encountered in securing steel within satisfactory limits of composition.

While heat treatment is normally under complete control of the consumer, it becomes of importance in selecting the type of steel. For example, slight superiority in performance of one composition might be counterbalanced by greater sensitivity to heat treatment or the necessity of using very high hardening heats for development of maximum endurance resulting in excessive scaling of tools, shorter furnace life, and generally higher production costs.

Assuming correctly balanced composition and heat treatment, the quality of metal may be considered as the summation of all other factors influencing the true performance of the steel.

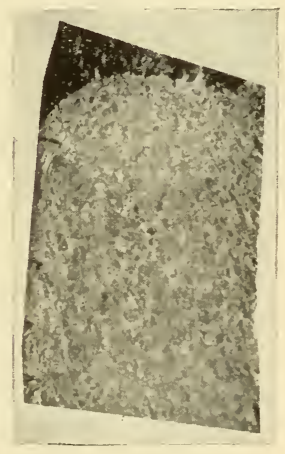

FIG. I4.- "Fish scale" or "flaky" fracture in high-speed tool steel.

Note quenching and grinding cracks.

It is largely because of variations in this respect that competitive breakdown tests have come into use, though their purpose is comparison of finished products, the performance of which is influenced by all factors mentioned. It is questionable, however, whether such tests have really answered the purpose.

As already indicated, the grading of brands or steels of nearly similar performance is not justified because the order of value may be entirely changed by minor variations in test conditions or by introduction of tools made from different lots of the same brand. Likewise there is no assurance that test bars supplied prospective purchasers for a purely competitive test really represent the average product of various manufacturers. In many cases they do, but in others a portion of the steel later supplied has been below 


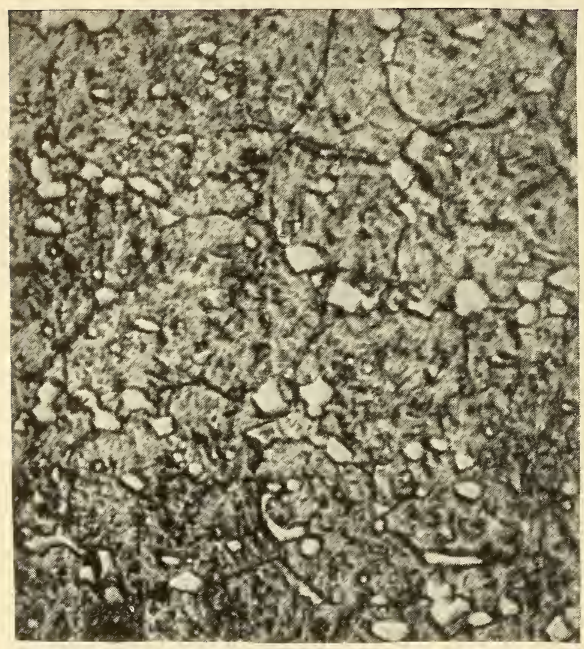

a

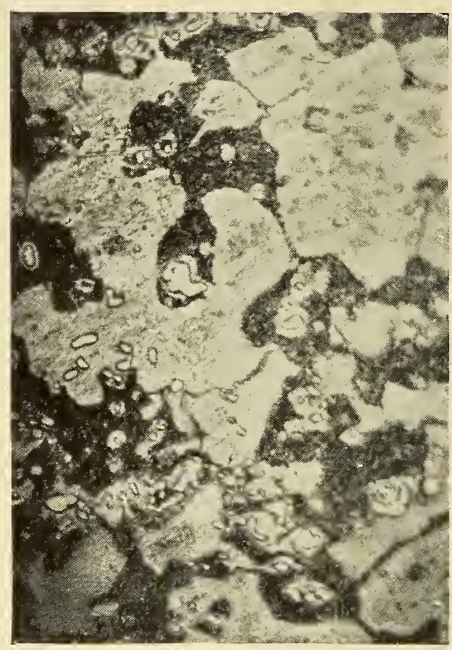

b

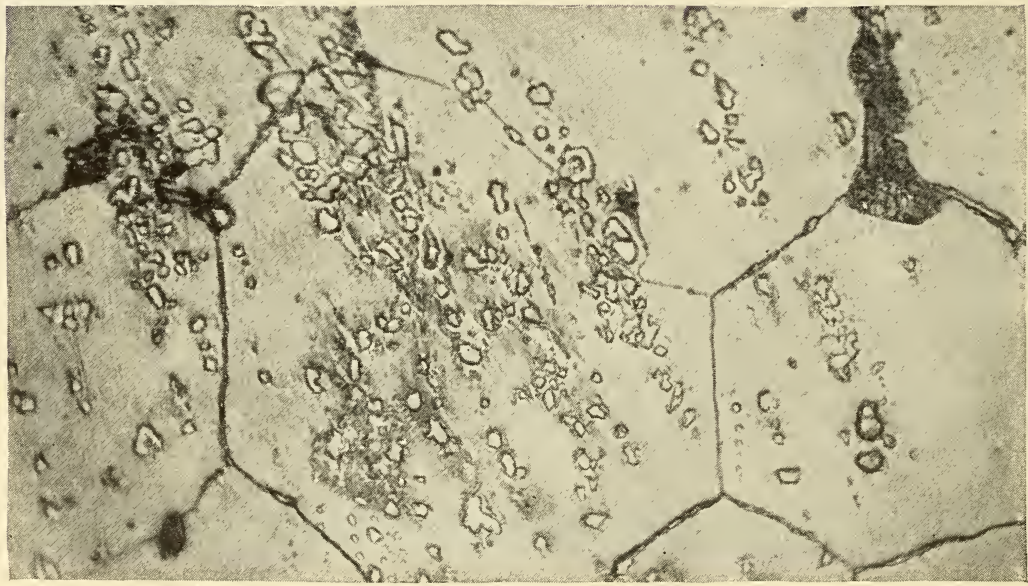

C

FIG. I5.-Photomicrographs of some of the lathe tools tested.

a. Characteristic structure of steel $\mathrm{X}$, oil quenched from $2,415^{\circ} \mathrm{F}$. and tempered at $1,090^{\circ} \mathrm{F} . \mathrm{X}_{\mathrm{I}, 000}$. b. Zone of partial melting observed in tools of steel S, oil quenched from $2,415^{\circ} \mathrm{F}$. and tempered at $\mathrm{I}, 090^{\circ} \mathrm{F}$. $\times 500$.

c. Section near the center of top surface of tool shown in $b . \times_{500 .}$ Shows "stringers" of hard constituents and very large grain size compared to that of steel $\mathrm{X}$.

All samples etched with 2 per cent nitric acid in alcohol. 


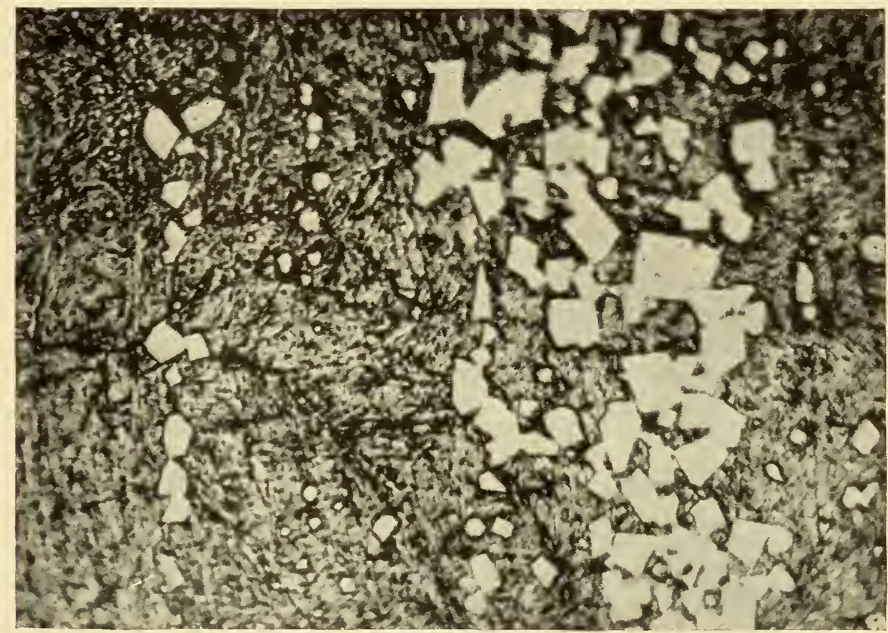

a

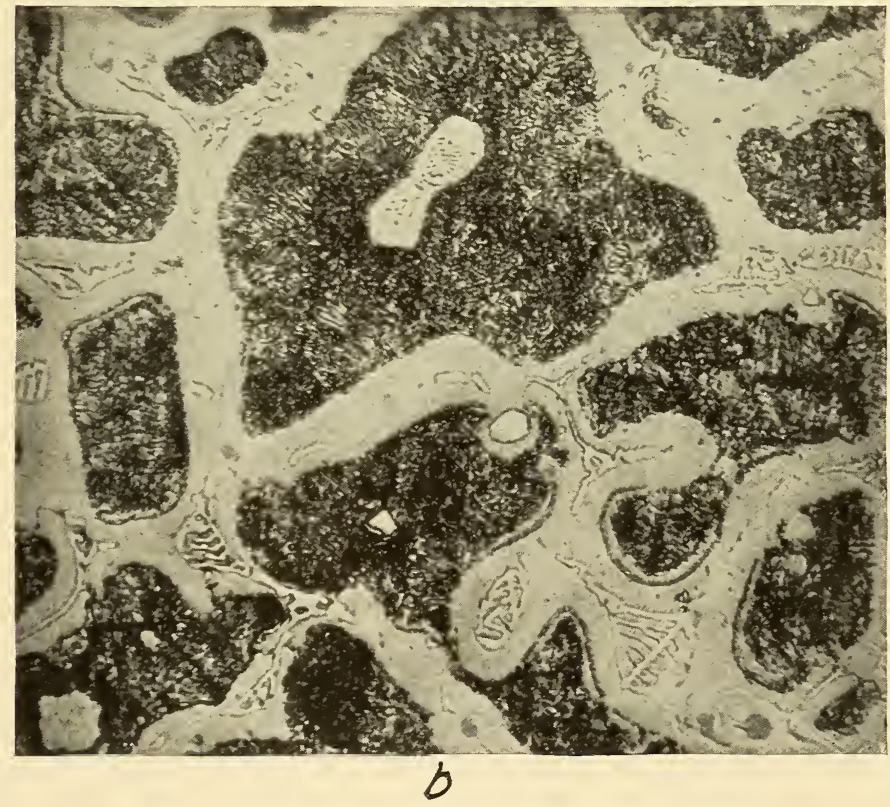

FIG. 16.--Photomicrographs of high-speed tool steels.

$a$. Another section of tool of brand $\mathrm{S}$ shown in Figures $1_{5} b$ and $c . \times 750$. Note segregation and alignment of hard constituents.

$b$. Outside surface of heat treated lathe tool of brand $\mathrm{S}$ which shows the effect of "sweating" on the final structure. Note the presence of a eutectic which is characteristic of cast steel. $\times 750$.

All samples etched with 2 per cent nitric acid in alcohol. 
the standard. Unless suitable methods are employed to check subsequent shipments against performance in the competitive test, the variations encountered may be much greater than the differences originally found between various steels.

Unless breakdown tests are made under conditions very closely approximating those of actual service, the results obtained will mean little or nothing and may actually be misleading, for, as

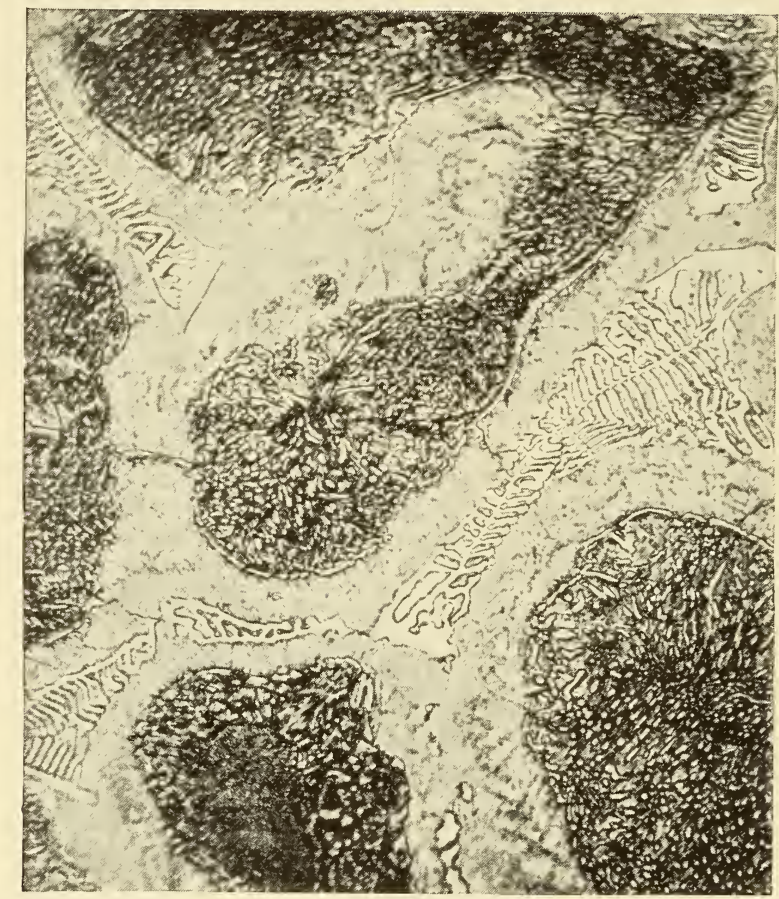

Fig. 17.-Structure of cast high tungsten-low vanadium highspeed steel. Introduced for comparison with structure shown in speed 16 b. $\times 750$.

Etched with 2 per cent nitric acid in alcohol.

previously shown, two types of steel may have comparable endurance under certain test conditions, but if these are materially changed the endurance of one may become much greater than that of the other.

Results of breakdown tests can be accepted only if a large number of tools are tested and the averages of at least two grinds are used in interpretation of results. They may, therefore, be employed to detect steel of highly questionable quality or to differentiate between steels or groups of widely different performance, but are not satisfactory for competitive comparisons used as the basis of 
purchase. Rather would the authors recommend the purchase of definite types of high-speed tool steel on the basis of price from manufacturers known to produce a uniformly high-grade product and the use of suitable inspection tests to insure the quality of various shipments made. The establishment of a selected list of producers should not be objectionable, for it would be open to all organizations able and willing to demonstrate high quality of product. Inspection tests might include macroscopic etching, fracture, chemical analysis, and even microscopic examination and breakdown tests, the last mentioned to insure the performance of steel being equal or better than a carefully prescribed minimum which could first be established.

\section{SUMMARY AND CONCLUSIONS.}

Important features developed or conclusions drawn from the described tests may be summarized as follows:

I. Breakdown tests, in which endurance of tools is determined under definite working conditions, are not satisfactory as the basis of purchase for high-speed tool steels.

2. While competitive comparisons of brands of nearly similar performance are not justified, owing to the qualitative nature of this type of test, relatively large differences may be ascertained with certainty providing sufficient tools are tested and averages of at least two grinds are used in interpretation of results.

3. In certain severe breakdown tests with roughing tools on 3 per cent nickel steel forgings, in which high frictional temperatures were produced, it was found that the performance of commercial low tungsten-high vanadium and cobalt steels was superior to that of the high tungsten-low vanadium type and special steels containing about $1 / 4$ per cent uranium or $3 / 4$ per cent molybdenum. The average power consumption in all cases was practically the same, so that this factor need not be introduced in comparisons which may be made on the basis of endurance of the tools.

4. Modification in test conditions, including small changes in tool angles but principally changes in cutting speed, more markedly affected the performance of steels containing cobalt or special elements, such as uranium or molybdenum, than that of the basic types (plain chromium-tungsten-vanadium steels).

5. The relatively poor endurance of the high tungsten steels under severe working conditions was not observed in more moderate tests, made on the same test log with equal cutting speed and depth of cut but with reduced feed, in which the frictional 
temperatures produced were not so high. Also in these latter tests the performance of the cobalt steels was better than either the low or high tungsten steels.

6. Hardness determinations and examination of fractures indicate that the various types of commercial high-speed steel show differences in behavior under heat treatment and in physical properties which probably are of importance under moderate working conditions and might counterbalance slight advantages in performance.

The authors acknowledge the cooperation of Lieut. Commander H. L. Merring, United States Navy, and the aid of 'T. G. Digges in carrying out many of the tests. The assistance of T. H. Johrden, machinist inspector, and J. W. Talley, assistant chemist, United States Naval Gun Factory, is also acknowledged.

\section{TABLES OF RESULTS.}

TABLE 1.-Summary of Compositions of 39 Brands of Modern High-Speed Tool Steels Based on Analysis of 66 Lots.

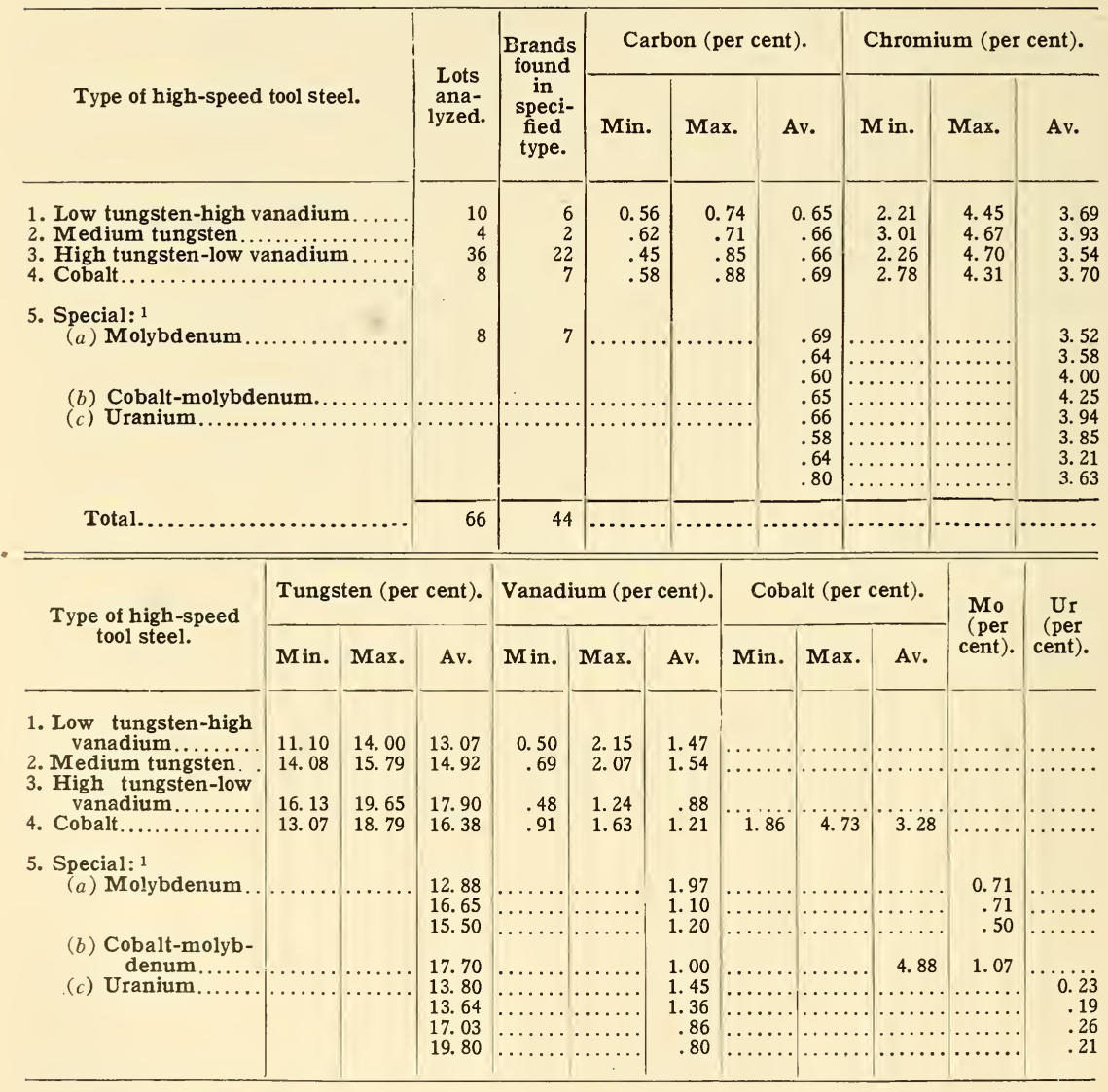

1 Typical compositions. 
TABLE 2.-Proportions of Manganese, Phosphorus, Sulphur, and Silicon Found in 66 Lots of Modern High-Speed Tool Steels Representing 39 Brands.

\begin{tabular}{|c|c|c|c|c|c|c|c|c|c|c|c|c|}
\hline \multirow{2}{*}{$\begin{array}{c}\text { Type of high-speed tool } \\
\text { steel. }\end{array}$} & \multicolumn{3}{|c|}{$\begin{array}{l}\text { Manganese (per } \\
\text { cent). }\end{array}$} & \multicolumn{3}{|c|}{$\begin{array}{l}\text { Phosphorus (per } \\
\text { cent). }\end{array}$} & \multicolumn{3}{|c|}{$\begin{array}{l}\text { Sulphur (per } \\
\text { cent). }\end{array}$} & \multicolumn{3}{|c|}{ Silicon (per cent). } \\
\hline & Min. & Max. & Av. & Min. & Max. & Av. & Min. & Max. & Av. & Min. & Max. & Av. \\
\hline All types. & 0.09 & 0.43 & 0.26 & 0.004 & 0.051 & 0.023 & 0.009 & 0.061 & 0.027 & 0.09 & ${ }^{1} 0.81$ & 0.27 \\
\hline
\end{tabular}

1 Only one lot contained more than $0.5^{\text {I }}$ per cent silicon.

TABLE 3.-Chemical Compositions of Cobalt High-Speed Tool Steels (Produced in the United States).

\begin{tabular}{|c|c|c|c|c|c|c|c|c|c|c|}
\hline \multirow{2}{*}{ Class of steel. } & \multirow{2}{*}{ Brand. } & \multicolumn{9}{|c|}{ Chemical composition (per cent). } \\
\hline & & C. & Cr. & W. & V. & Co. & Mn. & P. & S. & Si. \\
\hline (a) Low tungsten-low cobalt .......... & $\mathbf{A}$ & 0.68 & 3.96 & 13. 07 & 1. 63 & 1. 86 & 0.19 & 0.018 & 0.021 & 0.37 \\
\hline (b) Low tungsten-high cobalt... & $\begin{array}{l}\text { B } \\
\text { B }\end{array}$ & $\begin{array}{l}.67 \\
.76\end{array}$ & $\begin{array}{l}3.72 \\
3.41\end{array}$ & $\begin{array}{l}13.50 \\
14.01\end{array}$ & $\begin{array}{l}1.28 \\
1.60\end{array}$ & $\begin{array}{l}\text { 4. } 23 \\
4.73\end{array}$ & $\begin{array}{l}.42 \\
.34\end{array}$ & $\begin{array}{l}.023 \\
.029\end{array}$ & $\begin{array}{l}.023 \\
.061\end{array}$ & $\begin{array}{l}.39 \\
.27\end{array}$ \\
\hline (c) High tungsten-low cobalt ........ & $\begin{array}{l}\mathrm{C} \\
\mathrm{D}\end{array}$ & $\begin{array}{l}.66 \\
.88\end{array}$ & $\begin{array}{l}3.45 \\
4.29\end{array}$ & $\begin{array}{l}17.80 \\
18.79\end{array}$ & $\begin{array}{l}1.06 \\
1.30\end{array}$ & $\begin{array}{l}2.54 \\
2.92\end{array}$ & .20 & .022 & $\begin{array}{c}.019 \\
\ldots . . \ldots\end{array}$ & $\begin{array}{l}.45 \\
.10\end{array}$ \\
\hline (d) High tungsten-high cobalt . & $\begin{array}{l}\mathbf{E} \\
\mathbf{E} \\
\mathbf{F} \\
\mathbf{G}\end{array}$ & $\begin{array}{l}.58 \\
.72 \\
.59 \\
.68\end{array}$ & $\begin{array}{l}2.78 \\
3.26 \\
4.31 \\
3.68\end{array}$ & $\begin{array}{l}17.56 \\
18.40 \\
18.58 \\
17.51\end{array}$ & $\begin{array}{l}.93 \\
.86 \\
.91 \\
.97\end{array}$ & $\begin{array}{l}3.35 \\
3.10 \\
3.34 \\
3.27\end{array}$ & $\begin{array}{l}.09 \\
.08 \\
.17 \\
.30\end{array}$ & $\begin{array}{l}.016 \\
.020 \\
.024 \\
.014\end{array}$ & $\begin{array}{l}.026 \\
.017 \\
.016 \\
.010\end{array}$ & $\begin{array}{l}.18 \\
.11 \\
.10 \\
.22\end{array}$ \\
\hline
\end{tabular}

TABLE 4.-Proportions of Carbon Found in 66 Lots of Modern High--Speed Tool Steels Representing, 39 Brands.

\begin{tabular}{|c|c|c|}
\hline Carbon range (per cent). ${ }^{1}$ & $\begin{array}{l}\text { Steels } \\
\text { in given } \\
\text { limits. }\end{array}$ & $\begin{array}{l}\text { Total number } \\
\text { of steels in } \\
\text { given limits } \\
\text { (per cent). }\end{array}$ \\
\hline 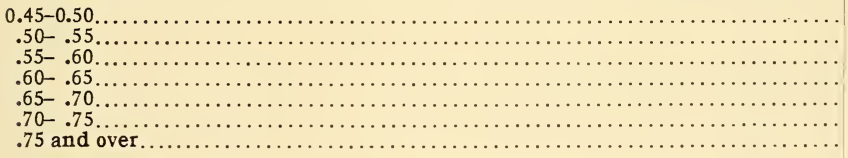 & $\begin{array}{r}1 \\
1 \\
6 \\
22 \\
22 \\
7 \\
7\end{array}$ & 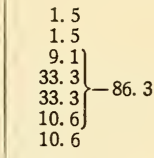 \\
\hline Total.. & 66 & 99.9 \\
\hline
\end{tabular}

1 Minimum value observed, 0.45 per cent carbon; maximum value observed, o.88 per cent carbon.

TABLE 5.-Proportions of Chromium Found in 66 Lots of Modern High-Speed Tool Steels Representing 39 Brands.

\begin{tabular}{|c|c|c|}
\hline Chromium (per cent). ${ }^{1}$ & $\begin{array}{l}\text { Steels } \\
\text { in given } \\
\text { limits. }\end{array}$ & $\begin{array}{l}\text { Total number of } \\
\text { steels in given } \\
\text { limits (per cent). }\end{array}$ \\
\hline 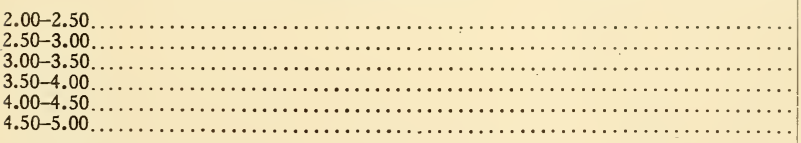 & $\begin{array}{r}2 \\
3 \\
18 \\
25 \\
14 \\
4\end{array}$ & $\begin{array}{l}\left.\begin{array}{l}\text { 3. } 0 \\
\left.\begin{array}{l}4.5 \\
27.3 \\
37.9 \\
21.2 \\
6.1\end{array}\right\}-65.2\end{array}\right\} 86.4\end{array}$ \\
\hline Total......... & 66 & 100.0 \\
\hline
\end{tabular}

\footnotetext{
1 Minimum value observed, 2.2 I per cent chromium; maximum value observed, 4. 70 per cent chromium.
} 
TABLE 6.-Compositions of American and English High-Speed Tool Steels.

[Cobalt and special steels not included.]

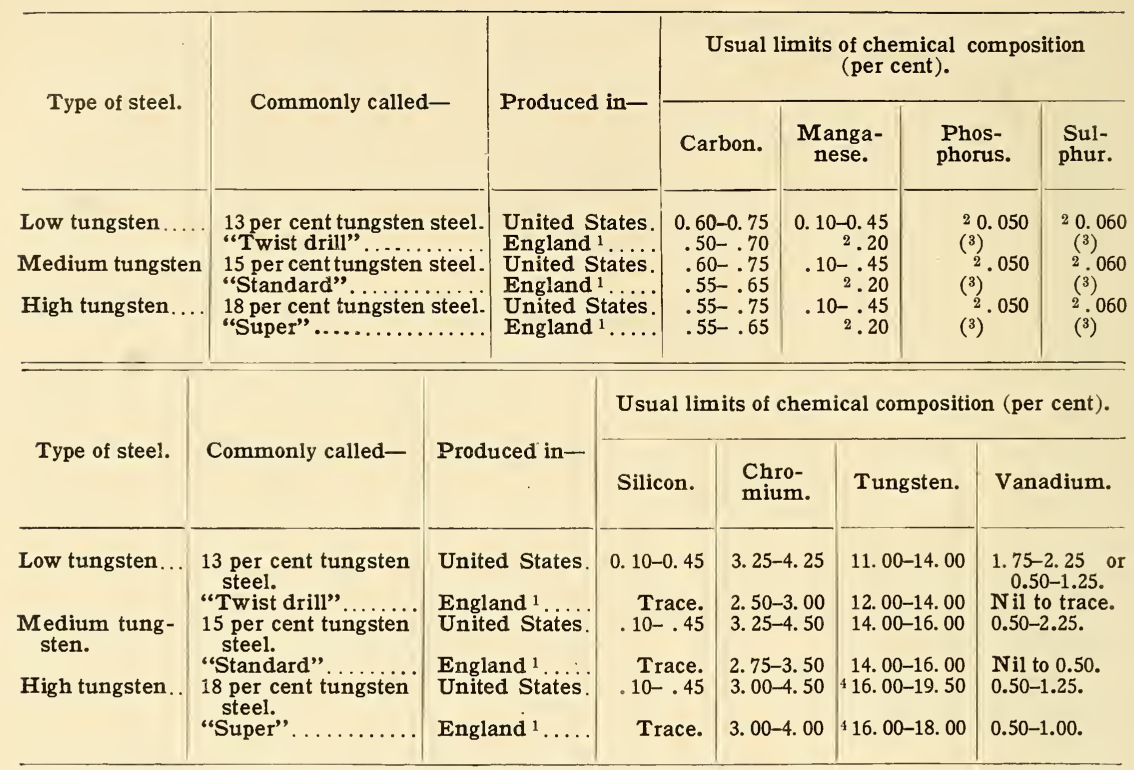

1 These limits obtained from T. H. Nelson, "Comparison of American and English methods of producing high-grade crucible steels," Raw Material, 4, No. I2, p. 424.

${ }_{2}$ Maximum.

3 Low as possible.

${ }^{4}$ Sometimes up to 20 per cent.

TABLE 7.-Conditions Under Which 1 by $\frac{1}{2}$ Inch Lathe Tools Were Tested.

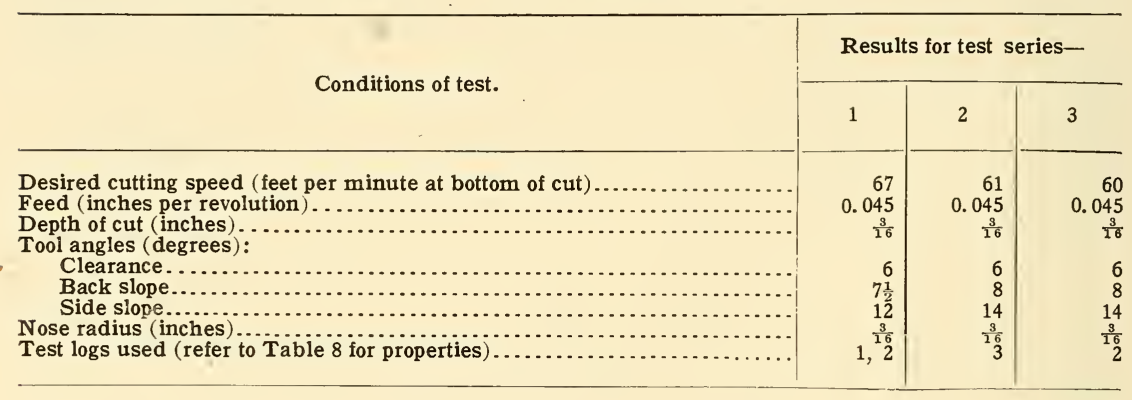


TABLE 8.-Properties of Test Logs Used.

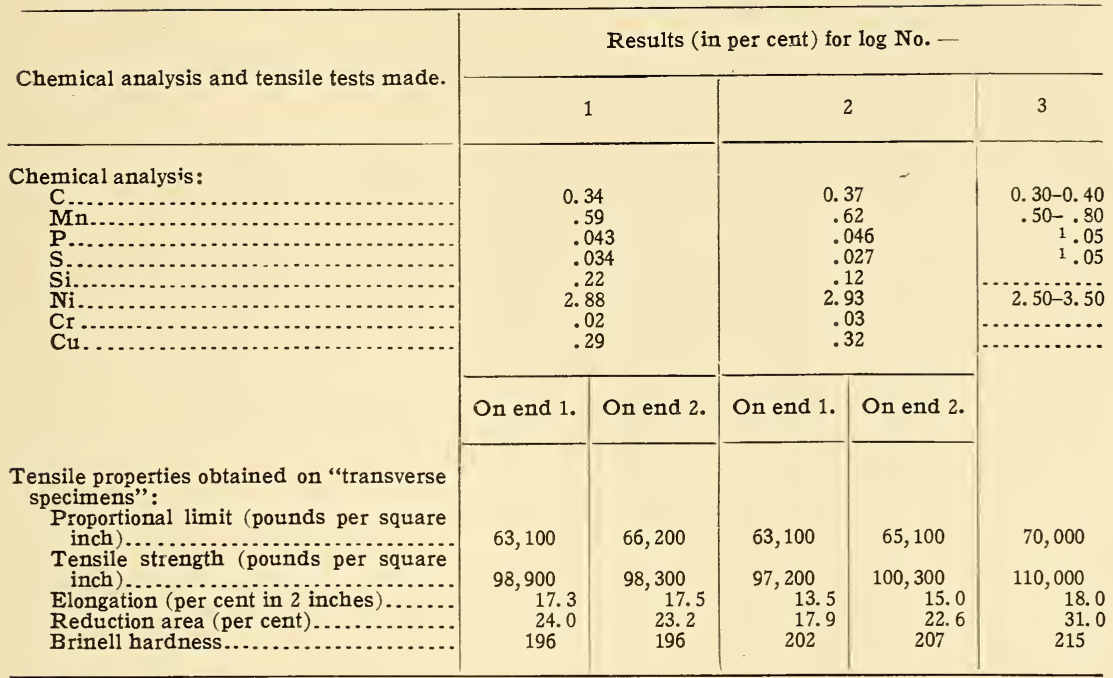

${ }^{1}$ Maximum.

TABLE 9.-Comparison of Performance of Various Brands of High-Speed Steels Based on Data Given in Table 12.

[Ten steels selected at random from those tested.]

\begin{tabular}{|c|c|c|c|c|c|}
\hline \multirow[b]{2}{*}{ Type of stee!. } & \multirow[b]{2}{*}{ Brand. } & \multicolumn{2}{|c|}{$\begin{array}{l}\text { Average time of cut } \\
\text { in minutes for- }\end{array}$} & \multicolumn{2}{|c|}{ Position in list for- } \\
\hline & & $\begin{array}{c}\text { First } \\
\text { set of } \\
\text { tests } \\
\text { (speed, } \\
67 \text { feet } \\
\text { per } \\
\text { minute). }\end{array}$ & $\begin{array}{l}\text { Second } \\
\text { set of } \\
\text { tests } \\
\text { (speed, } \\
61 \text { feet } \\
\text { per } \\
\text { minute). }\end{array}$ & $\begin{array}{l}\text { First } \\
\text { set of } \\
\text { tests. }\end{array}$ & $\begin{array}{l}\text { Second } \\
\text { set of } \\
\text { tests. }\end{array}$ \\
\hline 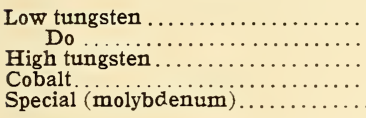 & $\begin{array}{l}\mathrm{B} \\
\mathrm{C} \\
\mathrm{O} \\
\mathrm{S} \\
\mathrm{T}\end{array}$ & $\begin{array}{r}10.06 \\
8.80 \\
7.87 \\
7.60 \\
6.18\end{array}$ & $\begin{array}{r}10.32 \\
11.68 \\
7.36 \\
14.56 \\
8.92\end{array}$ & $\begin{array}{l}1 \\
2 \\
3 \\
4 \\
5\end{array}$ & $\begin{array}{l}3 \\
2 \\
6 \\
1 \\
5\end{array}$ \\
\hline $\begin{array}{l}\text { Cobalt ............... } \\
\text { High tungsten ........ } \\
\text { Cobalt . .......... } \\
\text { Special (uranium) } \\
\text { High tungsten........ }\end{array}$ & $\begin{array}{l}\text { Q } \\
\mathrm{H} \\
\mathrm{R} \\
\mathrm{W} \\
\mathrm{F}\end{array}$ & $\begin{array}{l}5.52 \\
4.90 \\
4.85 \\
4.14 \\
4.01\end{array}$ & $\begin{array}{l}9.41 \\
6.15 \\
7.25 \\
6.39 \\
4.87\end{array}$ & $\begin{array}{r}6 \\
7 \\
8 \\
9 \\
10\end{array}$ & $\begin{array}{r}4 \\
9 \\
7 \\
8 \\
10\end{array}$ \\
\hline
\end{tabular}

TABLE 10.-Comparison of Performance of Various Types of High-Speed Tool Steels in Three Series of Lathe Tests. ${ }^{1}$

\begin{tabular}{|c|c|c|c|c|c|}
\hline \multirow{2}{*}{ Type of steel. } & \multicolumn{5}{|c|}{ Performance as per cent of best type- } \\
\hline & $\begin{array}{c}\text { First } \\
\text { series. }\end{array}$ & $\begin{array}{l}\text { Second } \\
\text { series. }\end{array}$ & $\begin{array}{l}\text { Third } \\
\text { series. }\end{array}$ & Total. & Average. \\
\hline 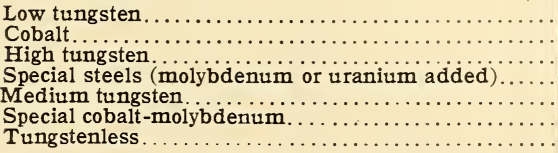 & $\begin{array}{r}100 \\
67.8 \\
56.3 \\
54.6 \\
54.1 \\
44.4\end{array}$ & $\begin{array}{r}94.1 \\
100 \\
55.3 \\
69.0 \\
55.8 \\
\cdots \cdots\end{array}$ & $\begin{array}{r}100 \\
97.3 \\
264.2 \\
51.7 \\
62.4 \\
84 \\
17.7\end{array}$ & $\begin{array}{r}294.1 \\
265.1 \\
175.8 \\
175.3 \\
172.3 \\
62.1\end{array}$ & $\begin{array}{r}98 \\
88 \\
59 \\
58 \\
57 \\
31\end{array}$ \\
\hline
\end{tabular}




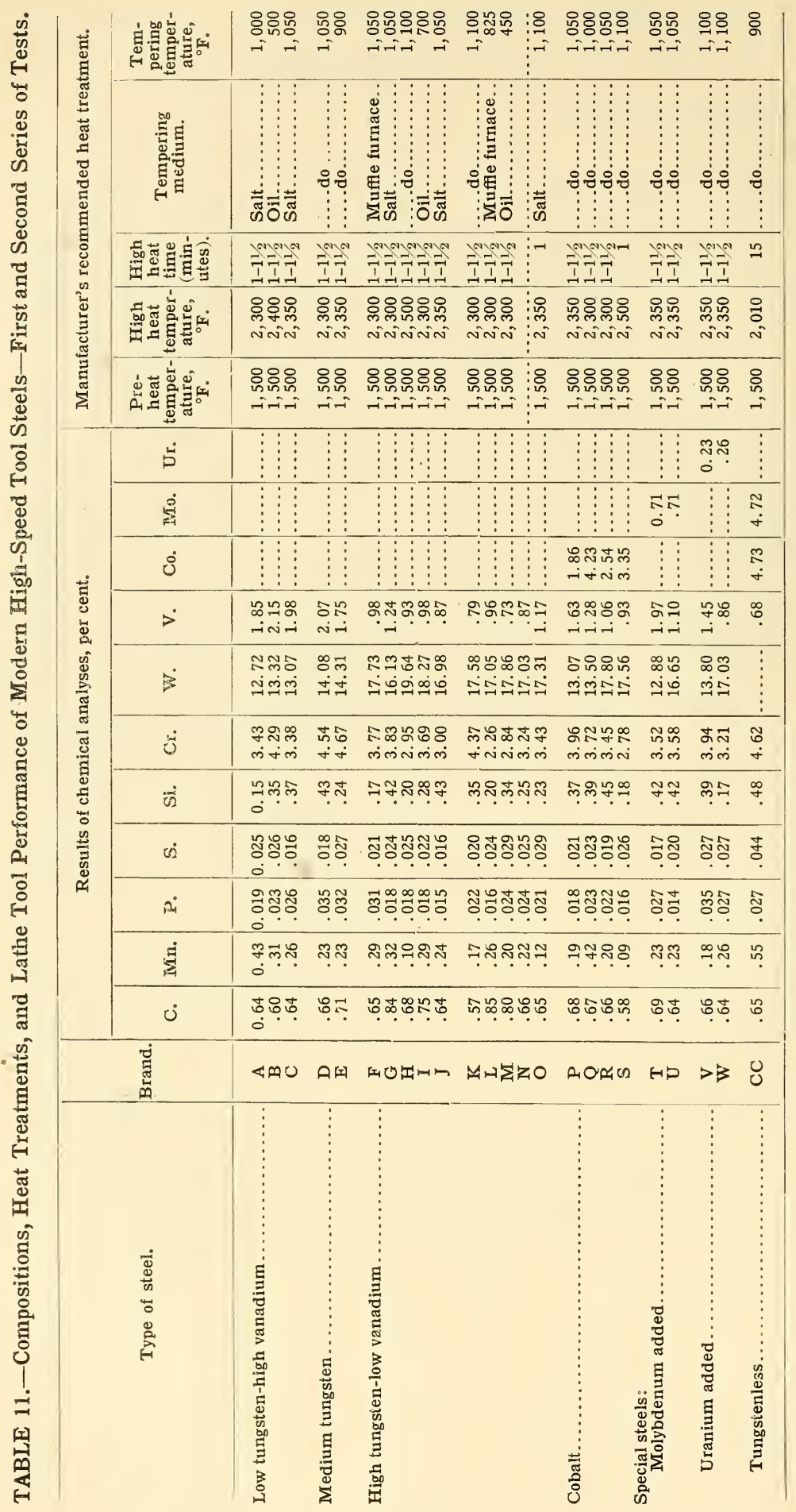




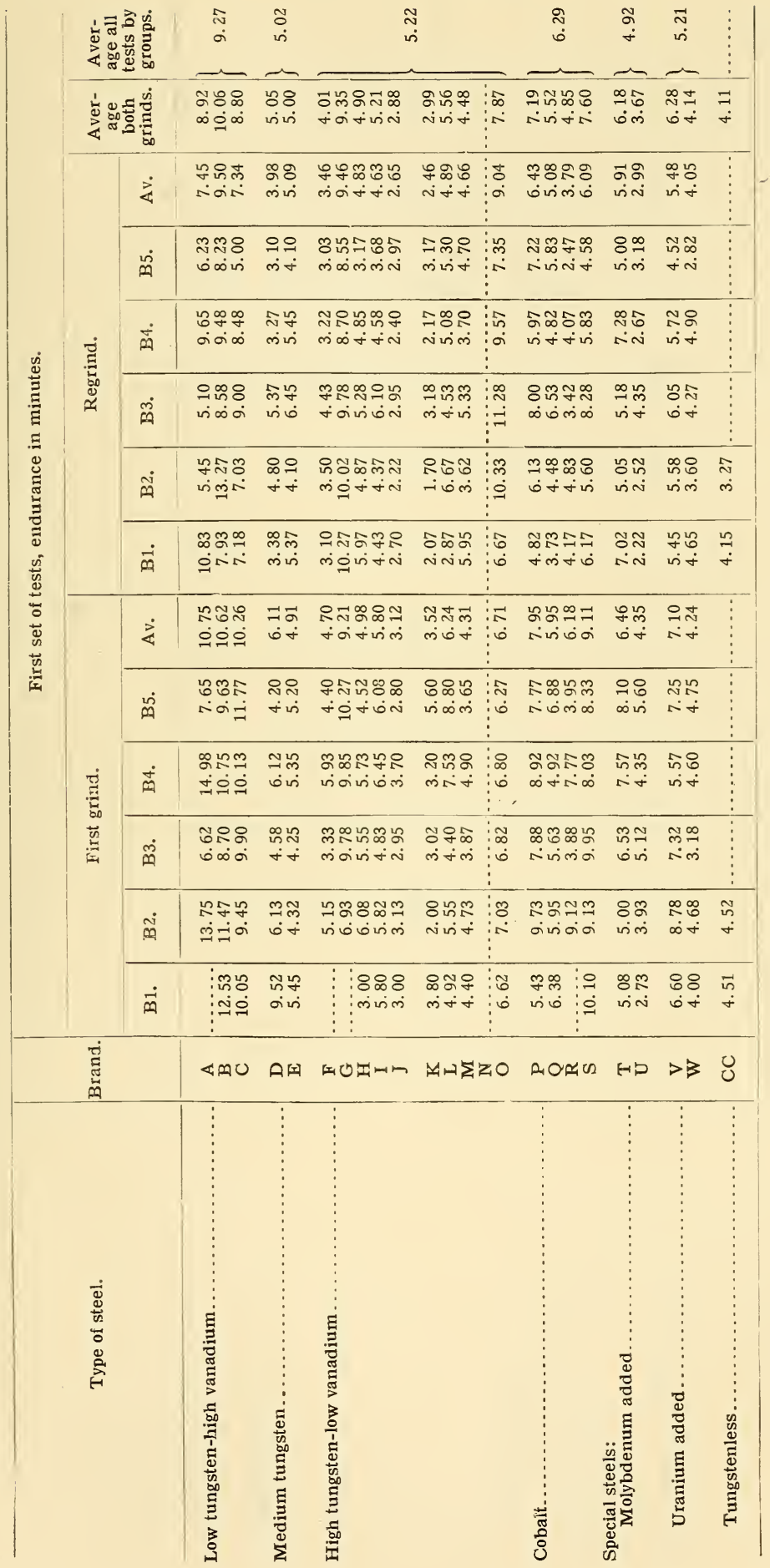




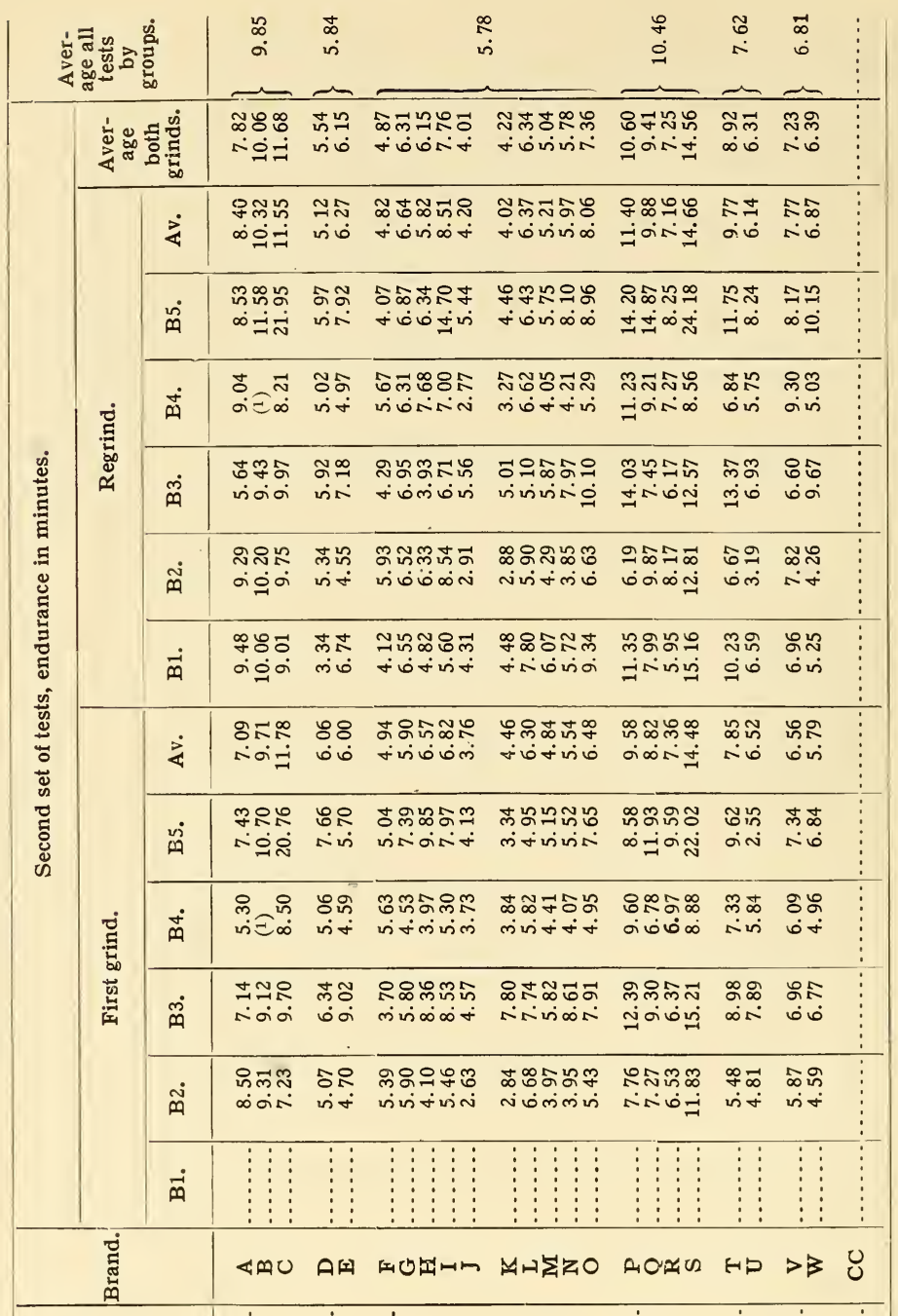

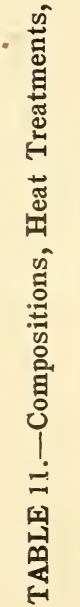

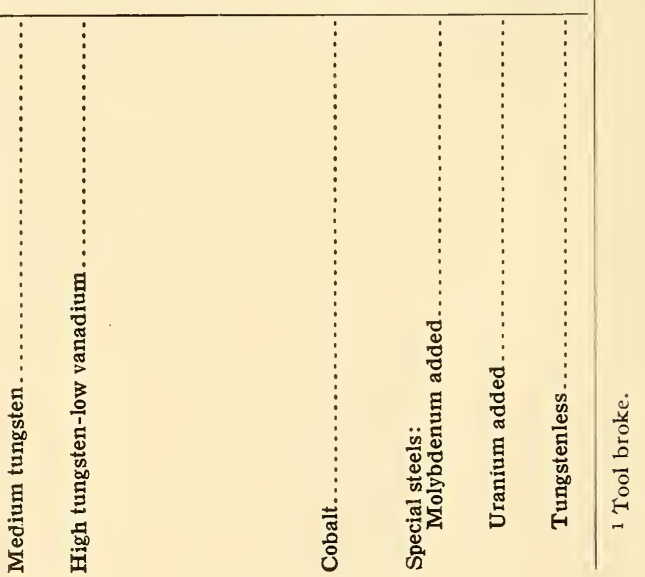




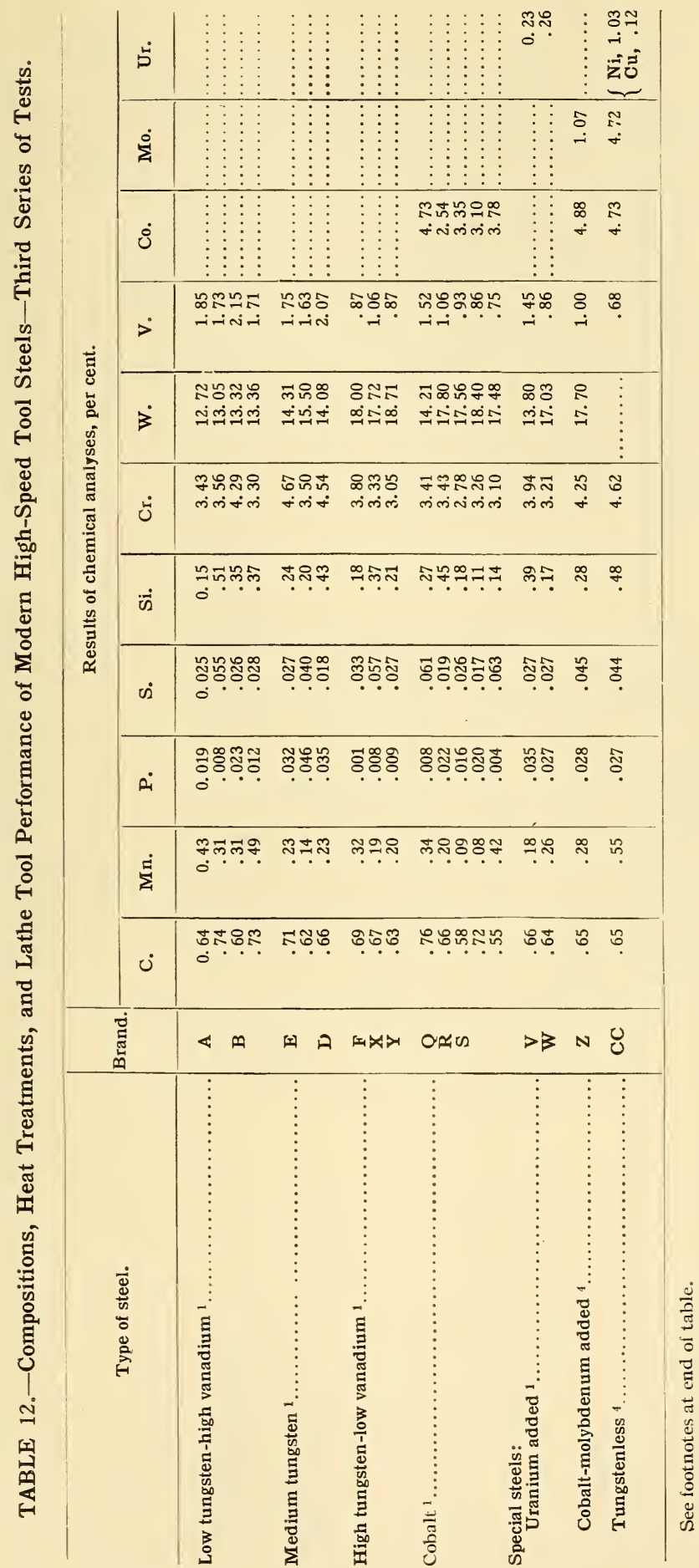




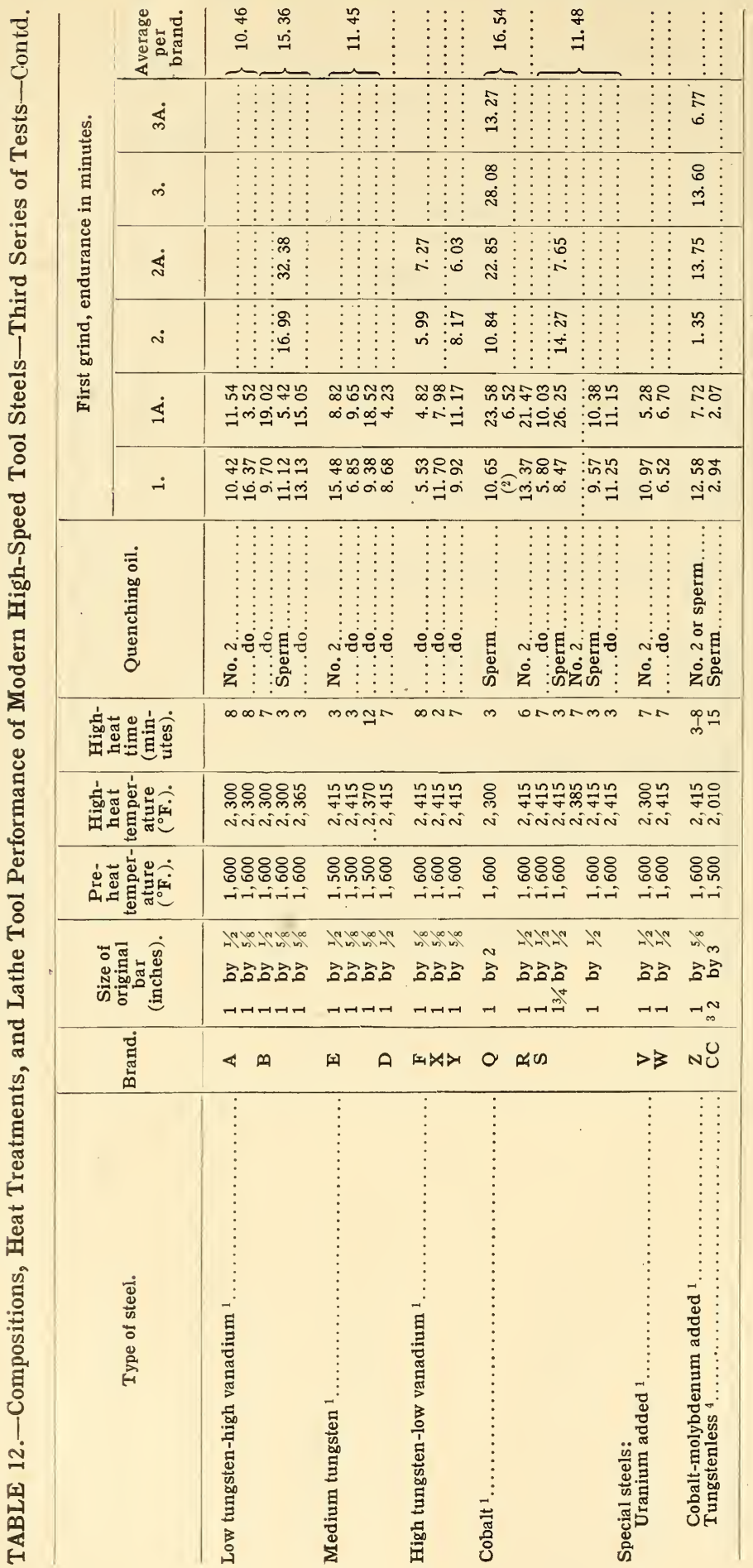




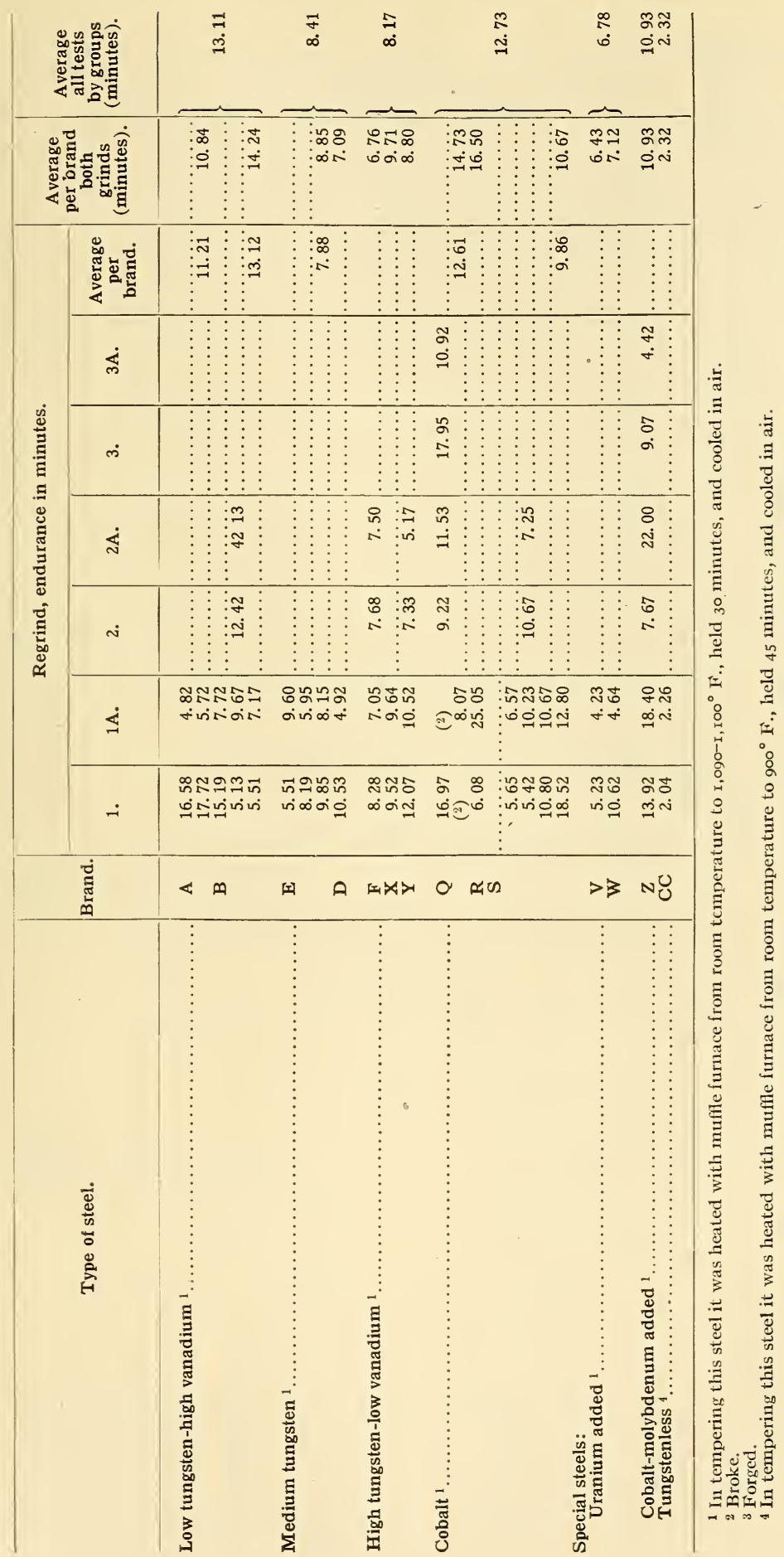




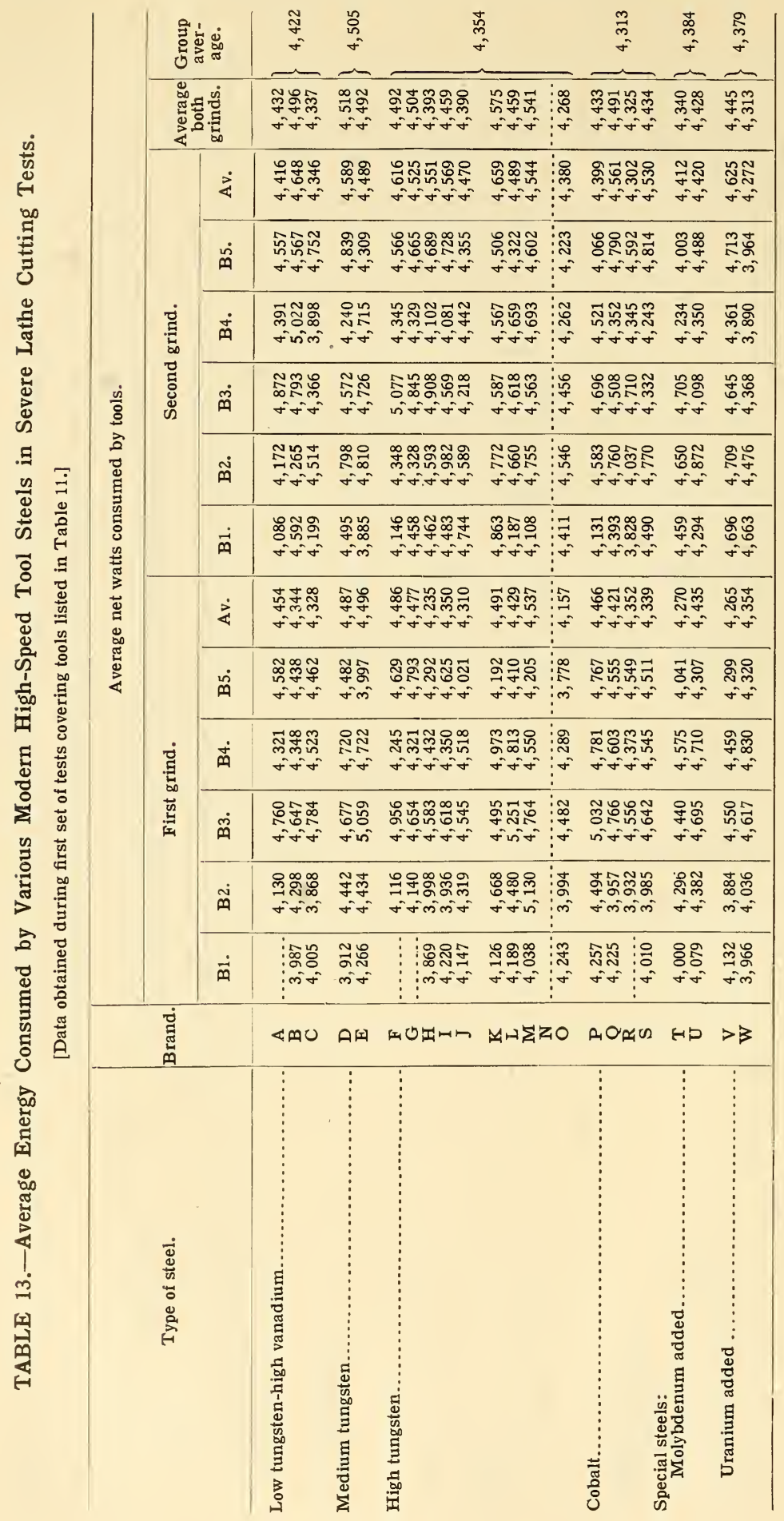


TABLE 14.-Effect of Variation in Feed on the Performance of Various Groups of High-Speed Tool Steels.

\begin{tabular}{|c|c|c|c|c|c|c|}
\hline \multirow[b]{2}{*}{ Group. } & \multirow[b]{2}{*}{ Brand. } & \multirow[b]{2}{*}{ Tool No. } & \multicolumn{4}{|c|}{ Endurance in minutes. ${ }^{1}$} \\
\hline & & & $\begin{array}{l}\text { Third } \\
\text { grind } \\
(0.031 \\
\text { feed })\end{array}$ & $\begin{array}{l}\text { Fourth } \\
\text { grind } \\
(0.031 \\
\text { feed }) .\end{array}$ & $\begin{array}{l}\text { Average, } \\
\text {-third } \\
\text { and } \\
\text { fourth } \\
\text { grinds } \\
(0.031 \\
\text { feed }) .\end{array}$ & $\begin{array}{c}\text { Average, } \\
\text { first and } \\
\text { second } \\
\text { grinds } \\
(0.045 \\
\text { feed }) .\end{array}$ \\
\hline Cobalt steels $\ldots \ldots \ldots \ldots \ldots \ldots \ldots$ & $\begin{array}{l}\mathrm{S} \\
\mathrm{S} \\
\mathrm{Q} \\
\mathrm{Q}\end{array}$ & $\begin{array}{l}\mathbf{x} 2 \mathrm{~A} \ldots \\
\text { T1A } \ldots \\
\text { A104-14A. } \\
\text { A104-14 . }\end{array}$ & $\begin{array}{l}23.60 \\
23.27 \\
39.08 \\
25.42\end{array}$ & $\begin{array}{l}22.83 \\
25.13 \\
17.30 \\
15.42\end{array}$ & $\begin{array}{r}\cdots \ldots \ldots \ldots \\
\cdots \cdots \\
\cdots \\
24.00\end{array}$ & 14. 36 \\
\hline High tungsten-low vanadium steels. & $\begin{array}{l}\mathbf{Y} \\
\mathbf{Y} \\
\mathbf{F} \\
\mathbf{X}\end{array}$ & $\begin{array}{l}\text { A105-2A } \ldots \\
\text { A105-2.... } \\
\text { A100-27... } \\
\text { A102-1... }\end{array}$ & $\begin{array}{l}17.27 \\
35.97 \\
16.20 \\
22.70\end{array}$ & $\begin{array}{r}22.30 \\
12.35 \\
9.57 \\
25.25\end{array}$ & $\begin{array}{r}\cdots \ldots \ldots \ldots \\
\cdots \cdots \\
\cdots \cdots \\
20.20\end{array}$ & 7.84 \\
\hline Low tungsten-high vanadium steels. & $\begin{array}{l}\mathbf{B} \\
\mathbf{B} \\
\mathbf{B} \\
\mathbf{A}\end{array}$ & $\begin{array}{l}\text { A101-26A. } \\
\text { A101-27A. } \\
\text { A101-26. } \\
\text { A103-41A. }\end{array}$ & $\begin{array}{l}11.48 \\
13.52 \\
22.48 \\
15.58\end{array}$ & $\begin{array}{l}19.03 \\
12.82 \\
10.45 \\
17.57\end{array}$ & $\begin{array}{r}\ldots \ldots \ldots \ldots \\
\cdots \ldots \ldots \ldots \\
\cdots \cdots \\
15.37\end{array}$ & 10. 08 \\
\hline
\end{tabular}

1 Tools were ground to $6^{\circ}$ clearance, $8^{\circ}$ back slope, and $14^{\circ}$ side slope, with radius of nose $\frac{3}{16}$ inch. Tests were made on $\log$ No. 2 at 60 feet per minute cutting speed, $\frac{3}{16}$ inch depth of cut, and feeds shown.

TABLE 15.-Heat Treatment and Performance of Small Lathe Tools Prepared from Three Types of High-Speed Tool Steels.

\begin{tabular}{|c|c|c|c|c|c|c|c|c|c|}
\hline \multicolumn{4}{|c|}{ Type of steel. } & Brand. & $\begin{array}{l}\text { Preheat } \\
\text { temper- } \\
\text { ature } \\
\left({ }^{\circ} \mathrm{F} .\right)\end{array}$ & \multicolumn{2}{|c|}{$\begin{array}{l}\text { High- } \\
\text { heat } \\
\text { temper- } \\
\text { ature } \\
\left({ }^{\circ} \mathrm{F} .\right)\end{array}$} & $\begin{array}{l}\text { High- } \\
\text { heat } \\
\text { time } \\
\text { (min- } \\
\text { utes). }\end{array}$ & $\begin{array}{l}\text { Temper- } \\
\text { ing tem- } \\
\text { perature } \\
\left({ }^{\circ} \mathrm{F} .\right) \text {. }\end{array}$ \\
\hline \multicolumn{4}{|c|}{$\begin{array}{l}\text { Low tungsten-high vanadium.... } \\
\text { High tungsten-low vanadium .... } \\
\text { Cobalt steel-high tungsten type. }\end{array}$} & $\begin{array}{l}\mathrm{B} \\
\mathrm{F} \\
\mathrm{R}\end{array}$ & $\begin{array}{l}1,600 \\
1,600 \\
1,600\end{array}$ & \multicolumn{2}{|c|}{$\begin{array}{l}2,300 \\
2,415 \\
2,300\end{array}$} & $\begin{array}{l}2 \\
2 \\
2\end{array}$ & $\begin{array}{l}1,090 \\
1,090 \\
1,090\end{array}$ \\
\hline \multirow{3}{*}{\multicolumn{3}{|c|}{ Type of steel. }} & \multirow{3}{*}{ Brand. } & \multicolumn{6}{|c|}{ Endurance in minutes. } \\
\hline & & & & \multicolumn{6}{|c|}{ First grind. } \\
\hline & & & & 1 & 2 & 3 & 4 & 5 & 6 \\
\hline \multicolumn{3}{|c|}{$\begin{array}{l}\text { Low tungsten-high vanadium } \ldots \ldots \ldots \ldots \ldots \ldots \\
\text { High tungsten-low vanadium } \ldots \ldots \ldots \ldots \ldots \ldots \ldots \\
\text { Cobalt steel-high tungsten type } \ldots \ldots \ldots \ldots \ldots \ldots\end{array}$} & $\begin{array}{l}\mathrm{B} \\
\mathrm{F} \\
\mathrm{R}\end{array}$ & $\begin{array}{l}26.90 \\
24.38 \\
25.73\end{array}$ & $\begin{array}{l}31.75 \\
36.10 \\
23.93\end{array}$ & $\begin{array}{l}25.95 \\
20.83 \\
30.37\end{array}$ & $\begin{array}{l}24.28 \\
26.85 \\
15.83\end{array}$ & $\begin{array}{l}28.78 \\
16.33 \\
14.47\end{array}$ & $\begin{array}{l}22.15 \\
17.43 \\
21.63\end{array}$ \\
\hline \multirow{3}{*}{ Type of steel. } & \multirow{3}{*}{ Brand. } & \multicolumn{7}{|c|}{ Endurance in minutes. } & \multirow{3}{*}{$\begin{array}{c}\text { Per- } \\
\text { form- } \\
\text { ance } \\
\text { as per } \\
\text { cent of } \\
\text { best } \\
\text { type. }\end{array}$} \\
\hline & & & & Regr & ind. & & & Aver- & \\
\hline & & 1 & 2 & 3 & 4 & 5 & 6 & grinds. & \\
\hline \multirow{2}{*}{$\begin{array}{l}\text { Low tungsten-high vanadium. } \\
\text { High tungsten-low vanadium. } \\
\text { Cobalt steel-high tungsten } \\
\text { type................................. }\end{array}$} & $\stackrel{B}{\mathrm{~B}}$ & $\begin{array}{l}32.40 \\
30.22\end{array}$ & $\begin{array}{l}29.97 \\
26.03\end{array}$ & $\begin{array}{l}17.40 \\
27.65\end{array}$ & & & 19. 87 & $\begin{array}{l}26.62 \\
24.57\end{array}$ & $\begin{array}{r}100 \\
92\end{array}$ \\
\hline & $\mathbf{R}$ & (1) & (1) & (1) & (1) & 20.38 & 20.38 & 21.99 & 81 \\
\hline
\end{tabular}

1 Tools broke in test. Size of tools, $1 / 4$ by $1 / 2$ inch, with radius of nose $\frac{3}{32}$ inch. Tool angles and properties of test log same as those used in test series No. 3 , Tables 7 and 8.

Washington, August I, 1922. 